\title{
From carbonate platform to euxinic sea - the collapse of an Early/Middle Devonian reef, Cantabrian Mountains (Spain)
}

\author{
Gerard B.S. van Loevezijn ${ }^{1, *} \&$ J.G.M. Raven ${ }^{2}$ \\ ${ }^{1}$ Jan Sluijtersstraat 7, 3443 HP Woerden, the Netherlands; e-mail: manipemieres@zonnet.nl \\ ${ }^{2}$ Naturalis Biodiversity Center, P.O. Box 9517, 2300 RA Leiden, the Netherlands; e-mail: han.raven@naturalis.nl \\ * corresponding author
}

\begin{abstract}
The Santa Lucía Formation represents the major phase in Devonian reef development of the Cantabrian Zone (Cantabrian Mountains, northwest Spain). In the present study the transition from the carbonate platform deposits of the Santa Lucía Formation to the overlying euxinic basinal deposits of the Huergas Formation is described. These transitional strata are connected to the Basal Choteč Event and represent a condensed sedimentation of micritic dark-grey and black limestones with an upward increase of dark shale intercalations with iron mineralisation surfaces and storm-induced brachiopod coquinas. The transitional beds are grouped into a new unit, the Cabornera Bed, which consists of limestone, limestone-shale and shale facies associations, representing a sediment-starved euxinic offshore area just below the storm wave base. Four stages in reef decline can be recognised: a reef stage, an oxygen-depleted, nutrient-rich stage, a siliciclastic-influx stage and a pelagic-siliciclastic stage. Additional geochemical and geophysical investigations are needed to verify the results presented herein.
\end{abstract}

Key words: Anoxia, Basal Choteč Event, Cantabria, carbon isotopes, Eifelian, Emsian

\section{Introduction}

Devonian reefs probably produced the largest amount of reefal carbonate during the entire Phanerozoic (Kiessling et al., 2003). Decompacted carbonate production rates of the Devonian in the Cantabrian Mountains show evidence of a significant increase in production from $90 \mathrm{~m}$ per myr in the Pragian to a peak of $780 \mathrm{~m}$ per myr in the Eifelian (Veselovsky et al., 2008). High subsidence of up to $40 \mathrm{~m}$ per myr, and a slowly rising eustatic sea level (Johnson et al., 1985) offered sufficient accommodation space for the development of the thick carbonate succession of the Lower/Middle Devonian Santa Lucía Formation. This formation marks the first major appearance of highly productive reef organisms in the Cantabrian Zone, indicating a shift of its palaeogeographical location along the margin of the Gondwana palaeocontinent to palaeotropical latitudes, adequate for reef growth. This succession is overlain by an up to 400 -m-thick dark shale succession of the Huergas Formation. Although the transition from the shallow-marine carbonate reef belt to the euxinic environment has been studied several times since the end of the twentieth century (García Alcalde, 1998; Vodrážková et al., 2013 among others), it remains puzzling.

The goals of the present study are 1) to describe the facies and facies distribution of the boundary interval between the Emsian/Eifelian carbonate 
platform deposits of the Santa Lucía Formation and the overlying Eifelian/Givetian pelagic shales of the Huergas Formation in the central part of the Cantabrian Zone, 2) to reconstruct the environmental evolution of the transition from carbonate shelf to pelagic environment, and 3) to establish the order of causes of decline and disappearance of the main Devonian carbonate development of the Cantabrian Mountains. The present paper outlines detailed stratigraphical sections of the upper boundary interval of the Emsian/Eifelian carbonate succession of Cantabria to facilitate comparisons of the turnover in palaeogeographically separate realms of the Cantabrian and Prague basins.

The Santa Lucía Formation yields a fauna of exceptional palaeontological relevance. The numerous geological investigations during the last fifty years have accumulated a large amount of lithological and palaeontological data. Pioneers such as De Coo (1974) and Méndez Bedía (1976) presented the first comprehensive sedimentological analysis of the Santa Lucía Formation. Later, Hofmann \& Keller (2006) introduced a sequence-stratigraphical approach to these deposits, and Méndez Bedía et al. (1994) presented a palaeontological analysis of the Devonian reef environment. Their work laid the foundation for the present study. In contrast to the Santa Lucía Formation, data on the overlying Huergas Formation are more scanty. García Ramos (1978) presented a lithostratigraphical study of these deposits.

The present study is part of a larger project on the stratigraphy of Devonian rocks in the southern Cantabrian Mountains by the former Department of Palaeontology and Stratigraphy, University of Leiden (the Netherlands), and is based on field campaigns during the early 1980s. Additional fieldwork was carried out in 2016. Two sections in a narrow valley of the Casares River near the village of Cabornera in the southern part of the Cantabrian Mountains were logged on a detailed bed-by-bed scale, and samples were analysed for lithology and palaeontology.

\section{Geological setting}

During the Early-Middle Devonian, Cantabria was situated in the southern subtropics between palaeolatitudes of about $35^{\circ}$ and $45^{\circ} \mathrm{S}$, along the northern margin of Gondwana, facing the Rheic Ocean (Fig. 1). Reefs were particularly abundant in the large, shallow inland seas, mostly on passive margin settings and extensive flooded continental interiors. A suite of micro-island plates have been labelled South European Archipelago (Copper \& Scotese, 2003), with a reef tract from Spain through the Montagne Noir and the Prague Basin of approximately $1,600 \mathrm{~km}$ in length.

Palaeozoic deposits of the Cantabrian Mountains are attributed to the Cantabrian Zone (Lotze, 1945), the external zone of the Variscan Iberian Massif in northwest Spain (Fig. 2A). During the Silurian and Devonian, prior to the onset of Variscan orogeny, sediments were deposited across a stable shelf area (Van Loevezijn, 1989). That area can be divided into three major palaeogeographical units: 1) the Asturian Geanticline or Cantabrian Block, which delivered the terrigenous detritus towards the surrounding shelf area; 2) the Asturo-Leonese facies area or Asturo-Leonese shelf, where most of the detritus was deposited, and 3) the Palentian pelagic facies area (Brouwer, 1964), which occurs as allochthonous units in a Carboniferous flysch basin in the southeastern part of the Cantabrian Zone.

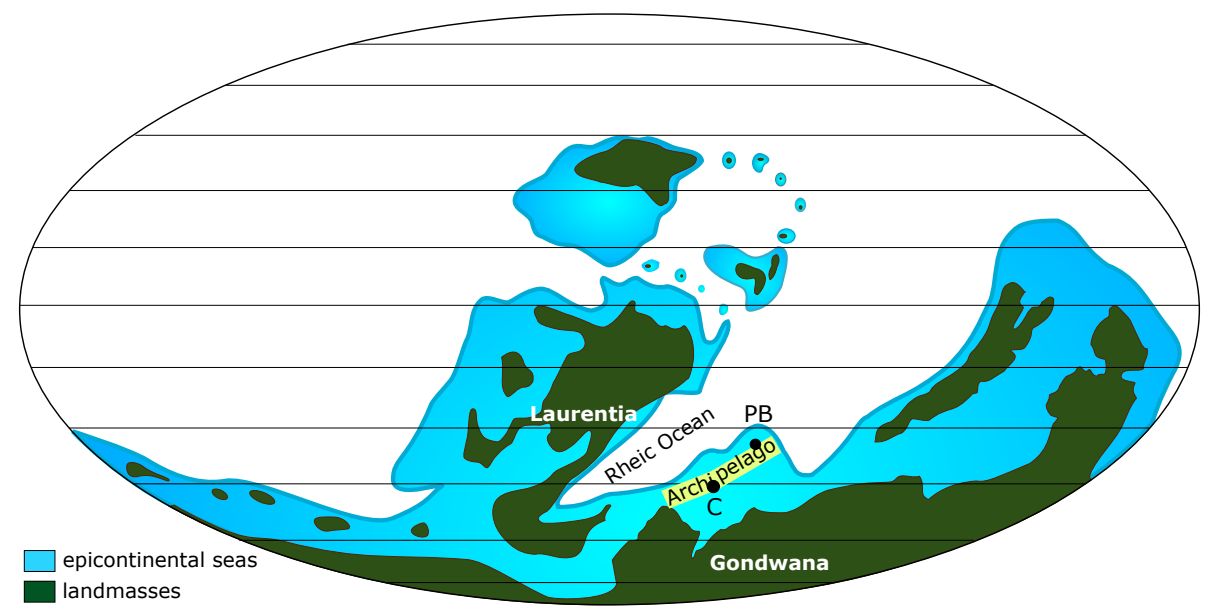

Fig. 1. Emsian palaeogeography (modified after Scotese, 2014). Prague Basin (PB) and Cantabria (C) indicated with black dots. 

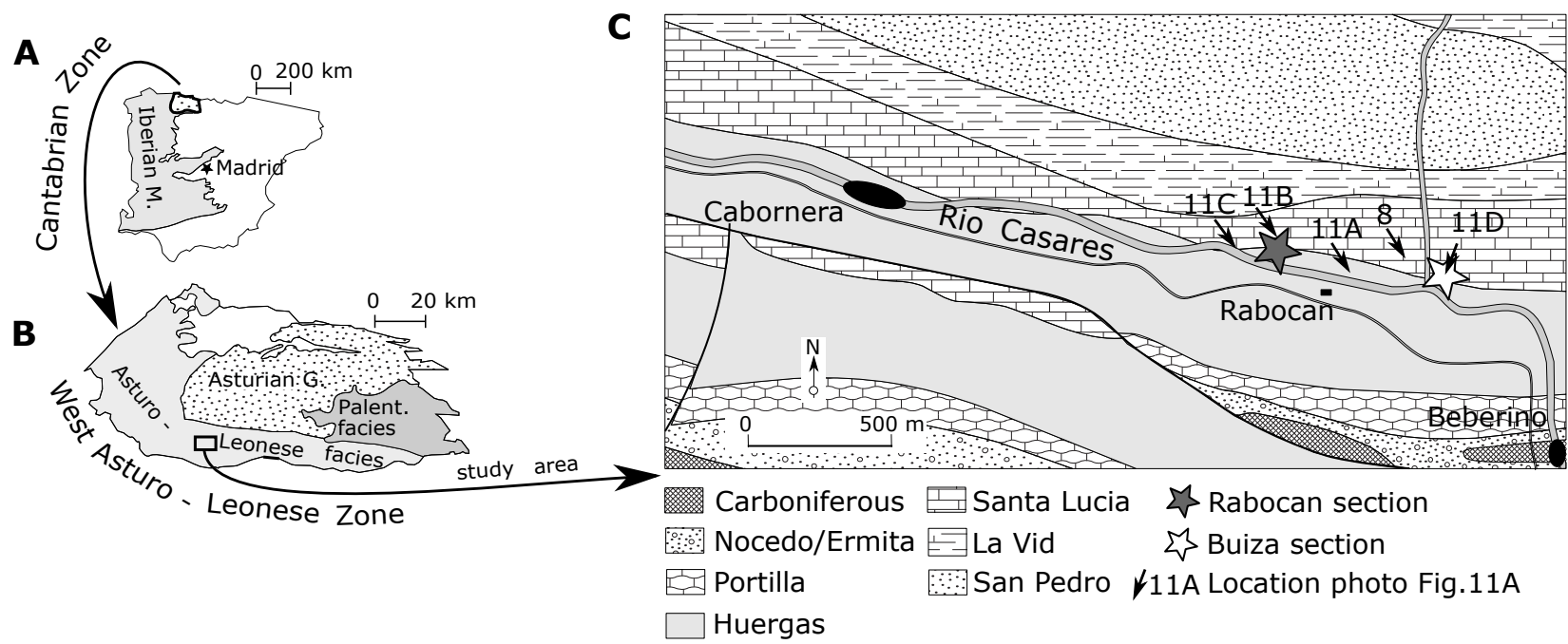

Fig. 2. A - Map of the Iberian peninsula with the Iberian Massif and location of the Cantabrian Zone; B - Map of the Cantabrian Zone showing the palaeogeographical units mentioned in the text; C - Geological map of the study area with locations of the sections (modified after Van Staalduinen, 1973).
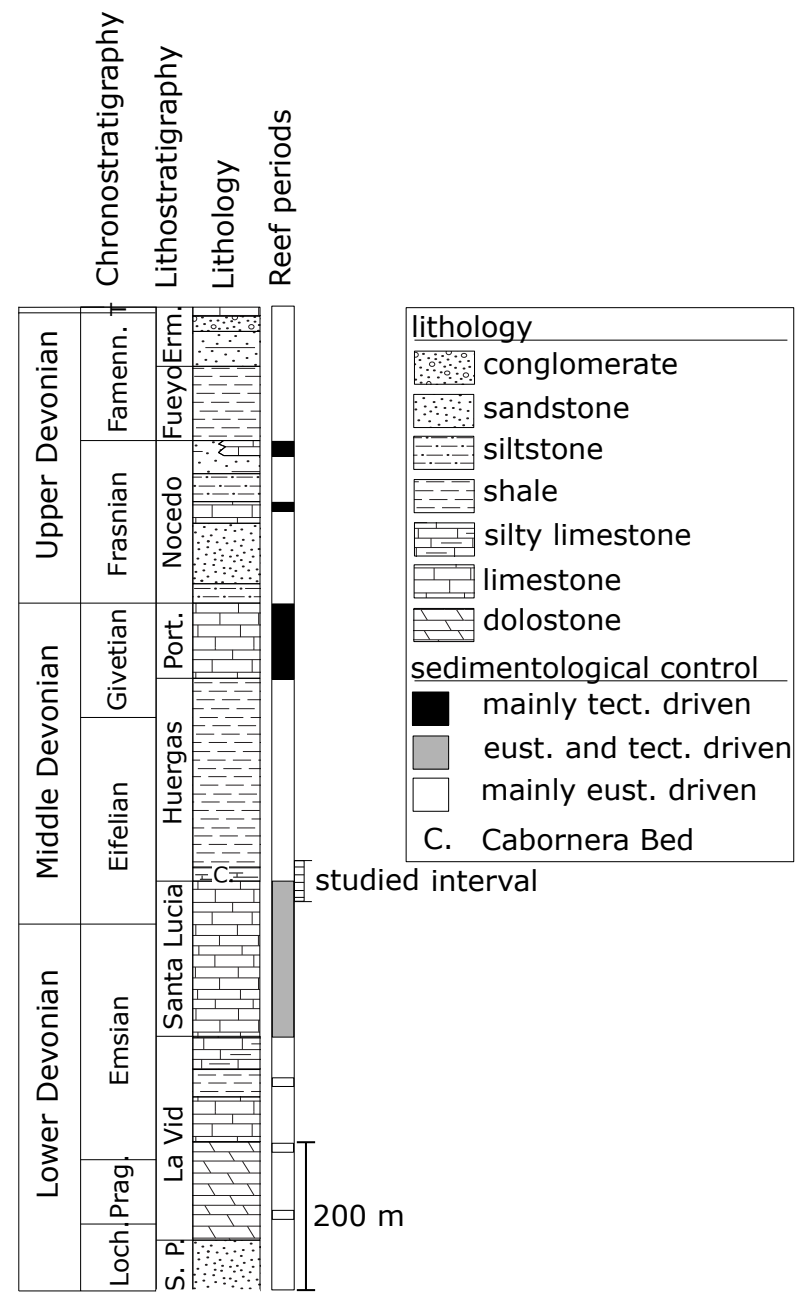

Fig. 3. Chronostratigraphy and lithostratigraphical units of the Asturo-Leonese facies area, with the distribution of reef periods in the Cantabrian Zone, and the stratigraphical location of the interval studied.
The shelf area of the Cantabrian Zone is bound in the south and west by a deeper area of the West Asturo-Leonese Zone (Fig. 2B). It is assumed that the Palentian facies originally formed in a position south or west of the Cantabrian Zone in the West Asturo-Leonese Zone (Raven, 1983; Frankenfeld, 1984). The Devonian limestone formations in the Asturo-Leonese facies area comprise a wealth of reef and reef-related deposits ranging in age from Pragian to Givetian and, locally, Frasnian (Fig. 3).

The Lower-Middle Devonian Santa Lucía Formation (approximately 250 metres thick) is the major Devonian carbonate platform unit of the Cantabrian Zone with its type section in the nearby Bernesga valley (Comte, 1959). The unit formed in a reef and reef-related carbonate environment. It is

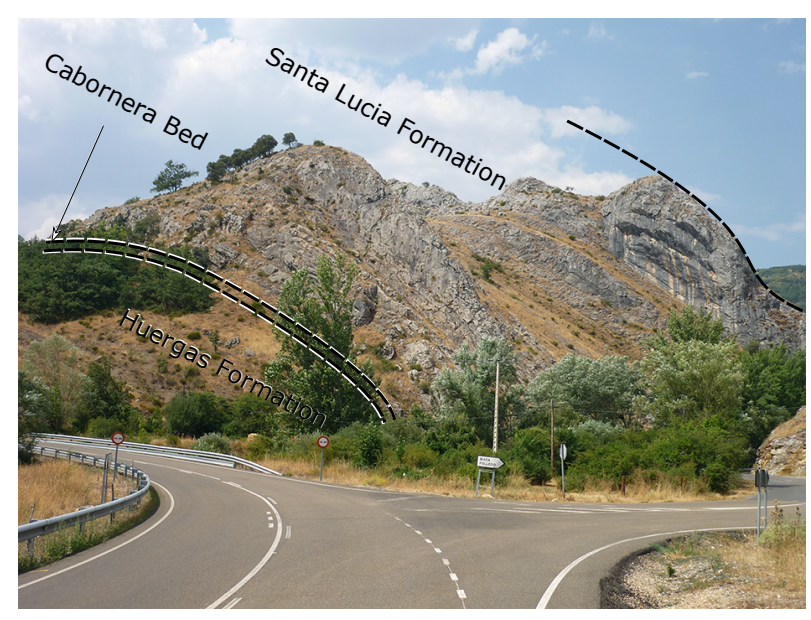

Fig. 4. Panoramic view of the Santa Lucía Formation, the Cabornera Bed and the basal part of the Huergas Formation at the road junction Cabornera-Buiza. 
well stratified and regularly bedded (Fig. 4). This is in contrast with the Givetian Portilla reef deposits, another major carbonate platform unit of the Cantabrian Zone, in which both thickness and facies vary significantly over short distances (Reijers, 1972; Raven, 1983). The Santa Lucía Formation is overlain by an euxinic shale succession of the Huergas Formation (Aramburu at al., 2004). The stratigraphical interval studied includes the uppermost part of the Santa Lucía Formation and the basal part of the overlying Huergas Formation, and is located in the central part of the Asturo-Leonese facies area of the southern Cantabrian Mountains in the vicinity of the village of Cabornera (Fig. 2C).

\section{Biostratigraphy}

The limestone of the Santa Lucia Formation spans the Polygnathus serotinus to Polygnathus costatus biozones (García López \& Sanz-López, 2002; Hofmann \& Keller, 2006) ( Fig. 5). The conodont Icriodus retrodepressus Bultynck, 1970 allows a good correlation with the base of the Polygnathus partitus Zone and thus with the Emsian-Eifelian boundary (García López \& Sanz-López, 2002). At the top of the formation a brachiopod association with large forms of "Uncinulus" orbignyanus (de Verneuil, 1850), Paraspirifer cultrijugatus (Roemer, 1844) and Alatiformia alatiformis Drevermann, 1970 occurs, which correlates with the Polygnathus partitus Biozone (García López \& Sanz-López, 2002). This brachiopod assemblage represents the OCA fauna of Struve (1982) which is typical of the pre-Basal Choteč Event (García Alcalde, 1998). Several associations of conodonts representing the costatus Biozone were identified from bioclastic bars at the top of the Santa Lucía Formation (García López, 1987; Van Loevezijn, 1988; García López \& Sanz-López, 2002). The upper boundary of the Santa Lucía Formation is sharp, with a change from light-grey coloured limestones to a several metres thick succession of dark shaly mudstones and wackestones. Sixty centimeters above the upper boundary surface of the Santa Lucía Formation, in the dark shaly mudstones, a rich conodont fauna of the P. costatus Biozone was identified by García López \& SanzLópez (2002). The dark shaly mudstone succession is overlain by shales of the Huergas Formation, of Eifelian and early Givetian age (Hofmann \& Keller, 2006). It should be noted that the full names of the costatus and partitus zones have changed because Vodrážková et al. (2011) elevated Polygnathus costatus partitus Klapper, Ziegler \& Mashkova, 1978 to species level.

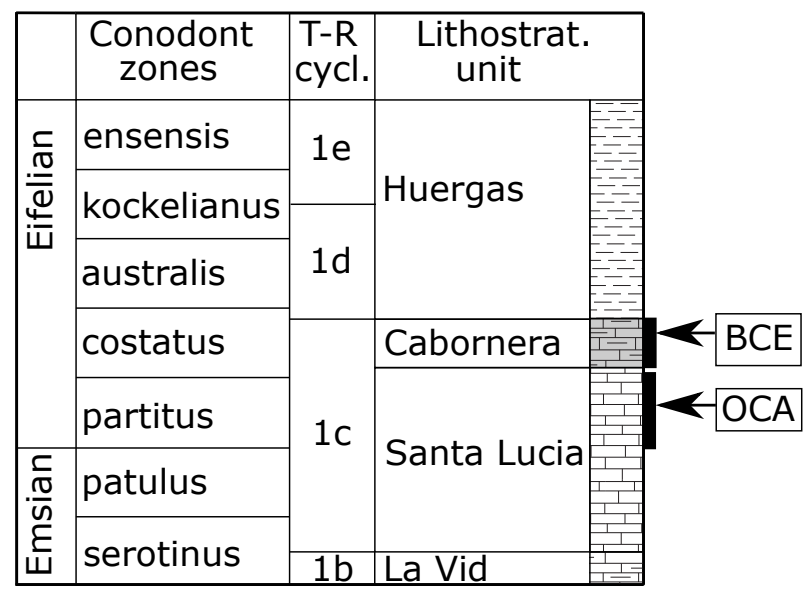

Fig. 5. Conodont zones of the Santa Lucía Formation, Cabornera Bed and Huergas Formation (conodont data after García-López \& Sanz-López, 2002; Hofmann \& Keller, 2006). Transgressive-regressive (T-R) cycles after Johnson et al. (1985). BCE-Basal Choteč Event; OCA = pre-Basal Choteč Event brachiopod fauna.

\section{Basal Choteč Event}

García Alcalde (1998) connected the sedimentary transition from light-coloured limestones of the Santa Lucía Formation to the overlying dark shaly sediments to the Choteč-jugleri Event of Walliser (1985) or to the Basal Choteč Event (BCE).

The BCE represents a deepening episode with distinctive facies and faunal changes, which is placed in the time interval corresponding to the Polygnathus partitus and Polygnathus costatus biozones (Vodrážková et al., 2013). At the BCE turn-

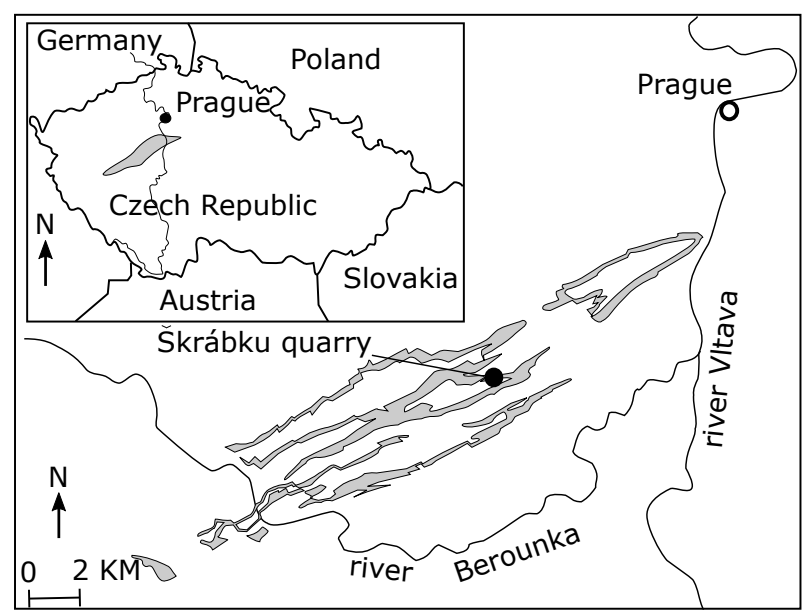

Fig. 6. Schematic map showing location of the Prague Basin (Czech Republic), the distribution of the Trébotov Formation and its equivalent and the Choteč Formation within that basin and the location of the Škrábku quarry section (modified after Berkyová, 2009). 
PRAGUE BASIN

Choteč, Skrábku quarry

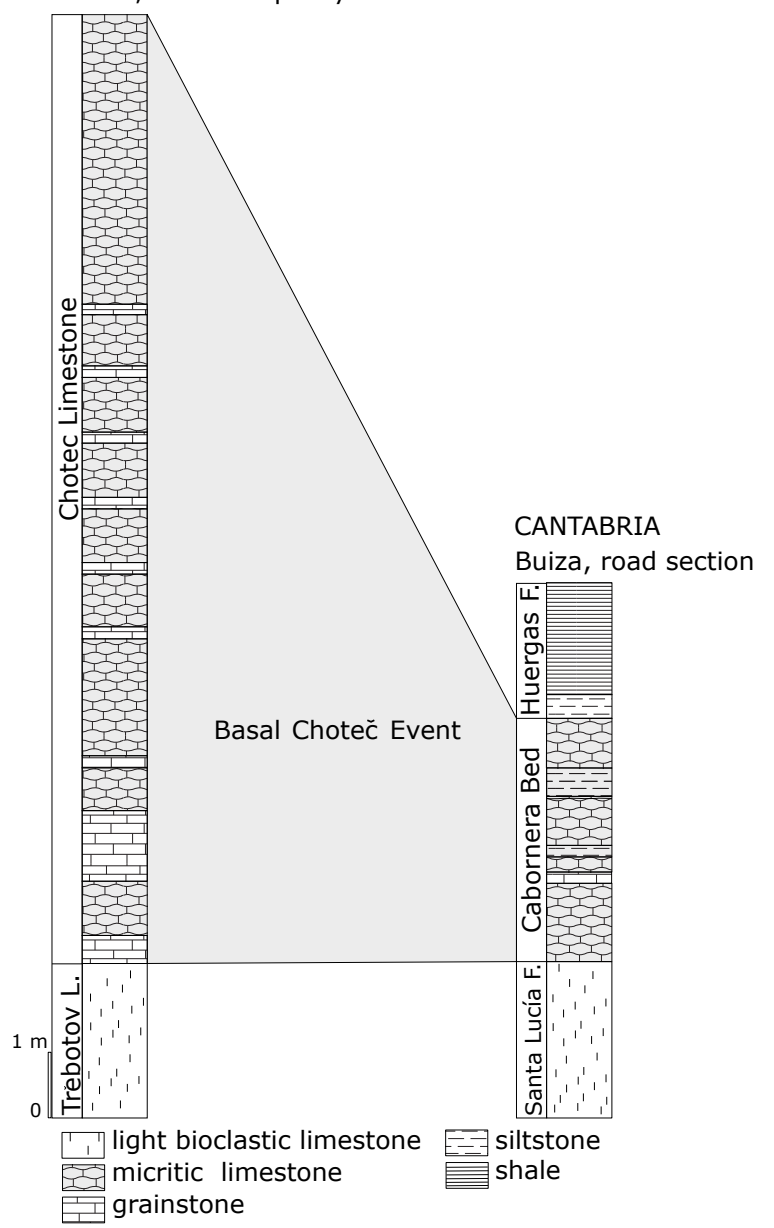

Fig. 7. Sections covering the Basal Choteč Event in the Czech Republic and Spain. over a profound faunal change took place among almost all faunal groups. Benthic assemblages, especially trilobite and brachiopod faunas, suffered important losses. The BCE facies change has been recorded from many areas across the globe, but the crucial question of correlations remains in many cases a matter of debate (House, 1996; Vodrážková et al., 2013).

The type section of the Basal Choteč Event in its type area, the Prague Basin, is located in the Škrábku quarry at the village of Choteč (Fig. 6). The event is documented by the occurrence of the Choteč Limestone (Choteč Formation, Eifelian) and its equivalents. The lithology changes from light-grey, bioturbated limestone of the underlying Třebotov Limestone to an alternation of dark-grey limestones and marls of the Choteč Limestone. The intercalated crinoidal, fining-upward grainstone beds are interpreted as calciturbidites deposited in outer ramp settings, with background sediments represented by dark-grey micritic limestones (Vodrážková et al., 2013). Oxygen deficiency is obvious from the dark colour of the micrite and from its impoverished benthic fauna. The Choteč Limestone of the Prague Basin can be correlated with the transitional succession between the Santa Lucia and Huergas formations in Cantabria (Fig. 7). Lithologically, this interval differs significantly from the underlying light-grey fossiliferous Santa Lucía limestones and from the overlying Huergas shales. In the present study the interval is referred to as the Cabornera Bed, named after the nearby village of Cabornera. In the Choteč Limestone, as well as in the Cabornera Bed, dark-
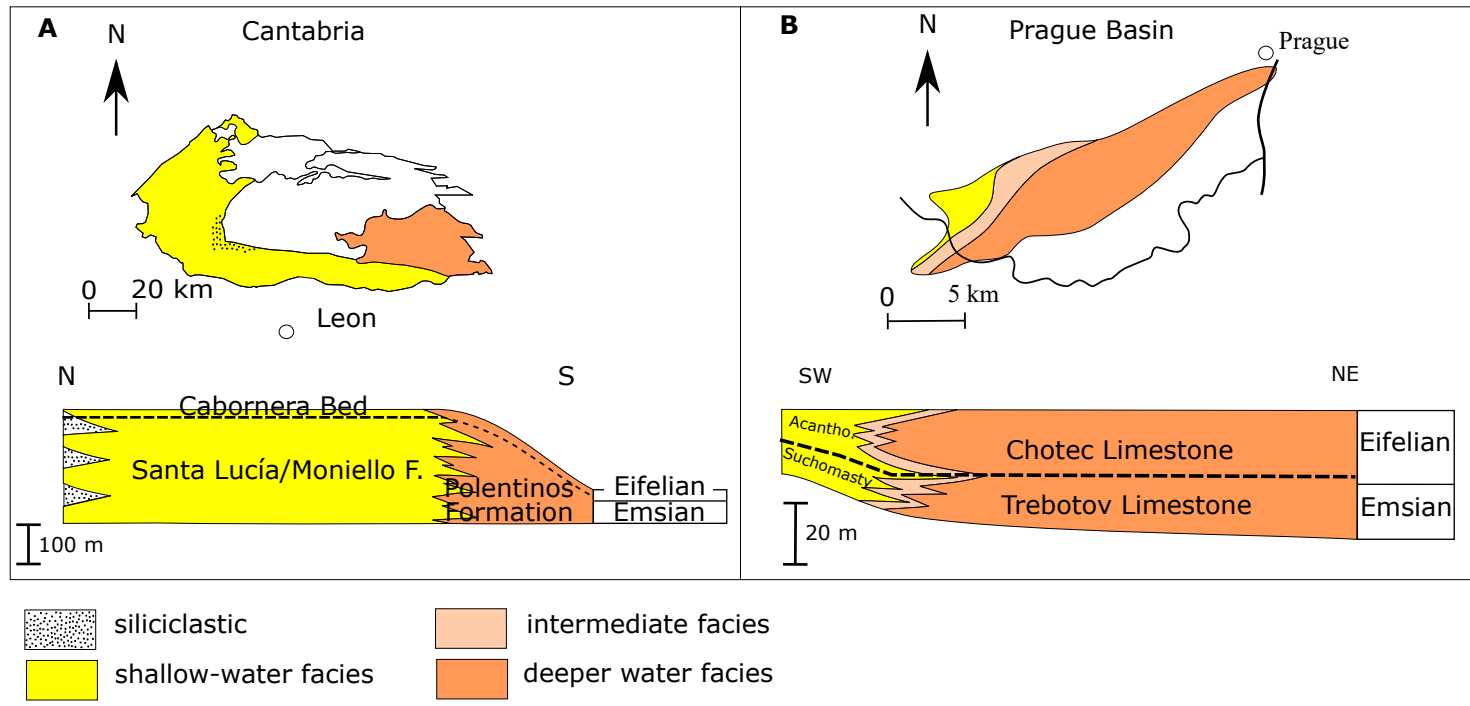

Fig. 8. A - Sketch map of the Early-Middle Devonian of Cantabria and simplified palinspastically corrected cross section across the Cantabrian Zone, with the deeper-water facies as the southern continuation of the shallow-marine facies; B - Early-Middle Devonian palaeogeography of the Prague Basin and simplified cross section (changed after Elrick et al., 2009). 
A Section Buiza

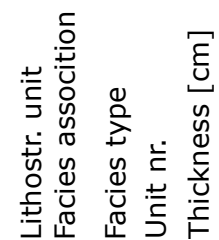

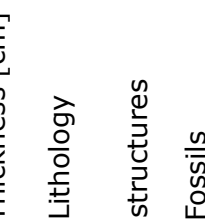

岛 Description

Interpretat.

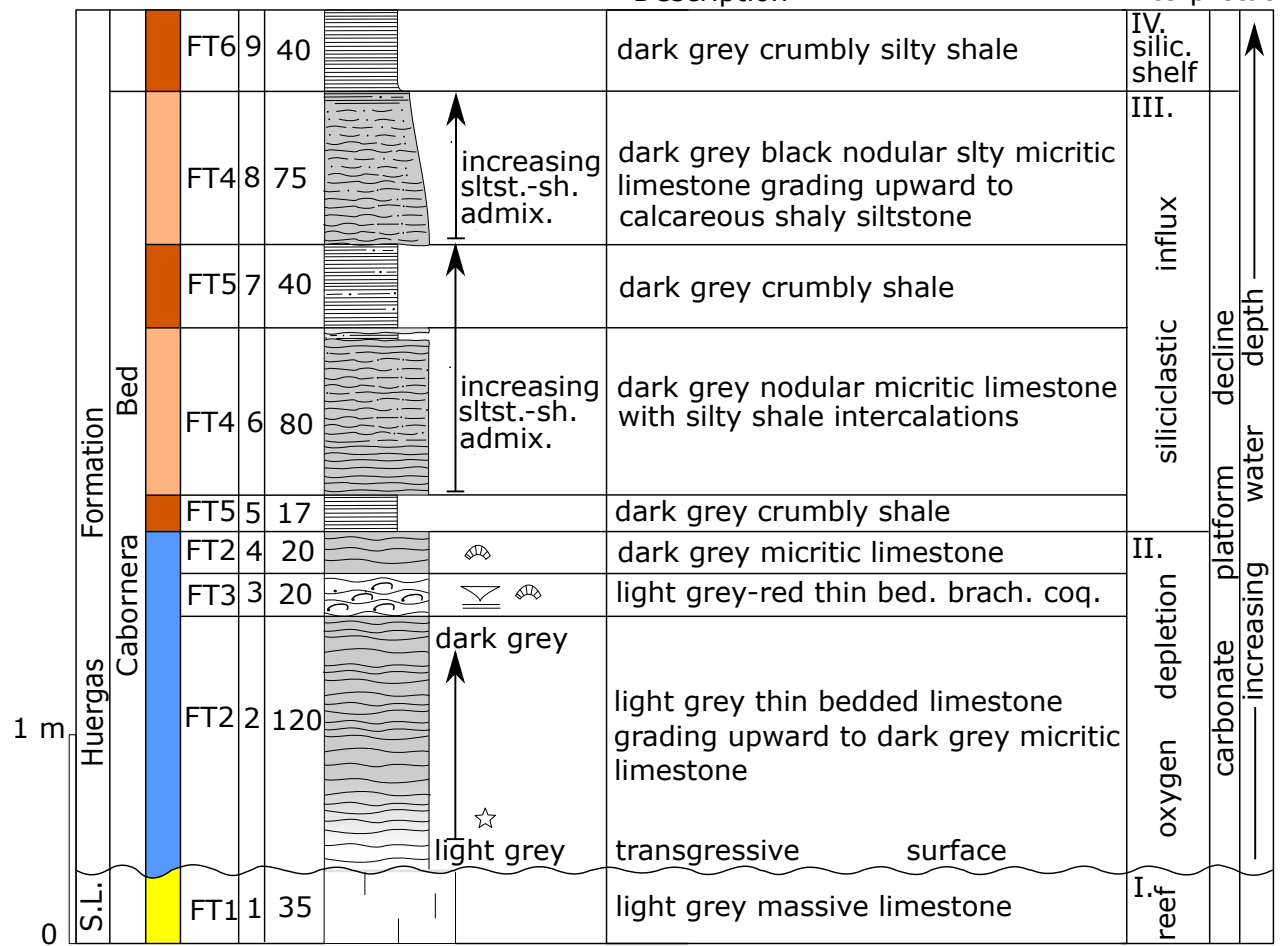

B Location section

Legend

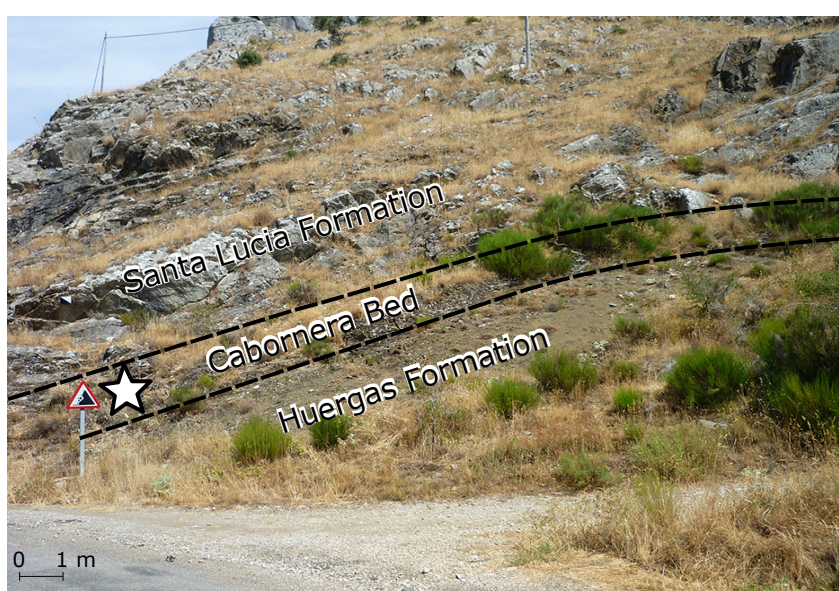

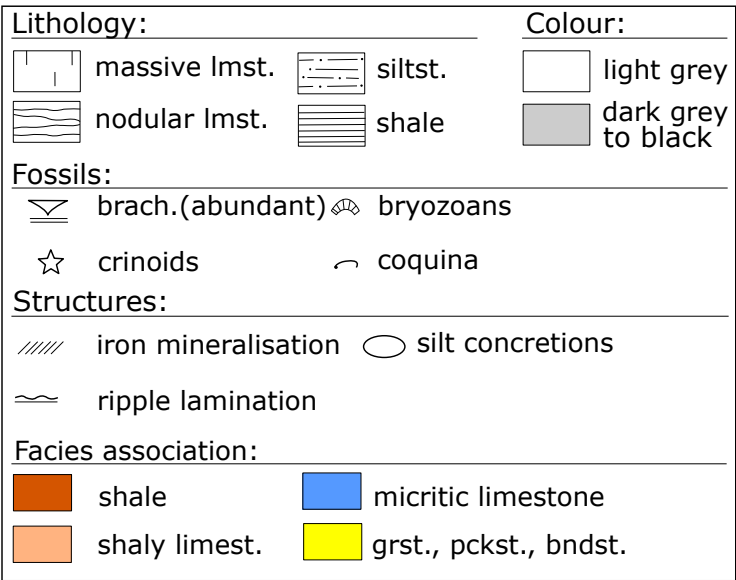

Fig. 9. A - Stratigraphy and interpretation of the Buiza section; S.L.F. = Santa Lucía Formation; H.Fm. = Huergas Formation; B - Location of the overturned section.

grey micritic limestones represent the major portion of the succession. Yet there are some differences: the Cabornera Bed succession contains an obvious upward increase in shale content with coquina intercalations, and the contact with the overlying shales is gradual. In the Choteč Limestone there is no upward increase in shale content and coquinas are absent; instead graded grainstone beds occur. Furthermore, sections of the Cabornera Bed studied are only 3.72 $\mathrm{m}$ and $4.39 \mathrm{~m}$ thick, whereas the Choteč Limestone sections described by Berkyová (2003) are usually significantly thicker (between 4 and $42 \mathrm{~m}$ ). 
In both the Prague Basin and Cantabria Middle Devonian shallow-water and deeper-water, carbonate-dominated facies areas can be distinguished (Fig. 8). In Cantabria a tectonic juxtaposition occurs of bathymetrically distant parts of the Devonian basin, and the deeper-water facies can be palaeogeographically interpreted as the southern continuation of the Asturo-Leonese platform (Frankenfeld, 1984). In the Prague Basin the Trebotov and Choteč limestones represent a deeper-water carbonate facies. In contrast, strata of the Santa Lucía Formation and the Carbonera Bed were deposited in the shallow-water realm.

The BCE is associated with low-oxygen conditions (Elrick et al., 2009). As it has been recognized both in shallow-marine neritic and deeper-marine pelagic deposits, the decrease in oxygen level may have been independent of water depth.

\section{Cabornera Bed}

Derivatio nominis: Cabornera, a village situated in the centre of the type area of the Cabornera Bed. Location type area: Situated in the Casares River valley, an east-west running tributary of the Bernesga River.

Location type section: co-ordinates $52^{\circ} 52^{\prime} 15.9^{\prime \prime} \mathrm{N}$, $5^{\circ} 41^{\prime} 10.7^{\prime \prime} \mathrm{W} ; 500 \mathrm{~m}$ north of Beberino, at the road junction to Buiza, on the eastern side of the road (Fig. 9).

The Cabonera sections were studied in the Casares River valley. The road between the junction to Buiza and Cabornera is located within the Huergas shales close to the top of the Santa Lucía limestone succession (Fig. 2C). The boundary between the Huergas and Santa Lucía formations crops out along the northern side of the road. The steep slope provides sections of acceptable quality; even the shales of the Huergas Formation are well exposed. The transition from the limestone to the shale was studied in two sections; one at the road junction to Buiza, the other $100 \mathrm{~m}$ west of the exit to the Rabocan restaurant (Fig. 2C). Each section studied starts with light-grey massive limestones of the uppermost part of the Santa Lucía Formation. The overlying Cabornera Bed consists of a condensed succession of dark-grey and black micritic limestones and shales with a few bioclastic intercalations. An iron mineralisation crust (composed mainly of limonite and goethite with hematite concretions) occurs immediately above the light-grey limestones of the Santa Lucía Formation.

\section{Description of facies}

Based on lithological features and faunal content the Cabornera Bed can be subdivided into a number of facies types, described and interpreted below. For the purpose of the present study a brief lithological summary of the underlying Santa Lucía limestones and the overlying Huergas shales is presented in order to position the transitional Cabornera Bed.

\subsubsection{Santa Lucía Formation}

Facies type 1 (FT1): well-stratified, light-grey fossiliferous limestone

Description: Within these deposits a wide spectrum of reef-related facies types can be recognised, arranged into several facies associations. For detailed facies analysis, reference is made to De Coo (1974), Méndez Bedía (1976) and Hofmann \& Keller (2006). Interpretation: The basic interpretation from the above-mentioned studies is that the Santa Lucía Formation represents a carbonate shelf with a well-developed lagoonal/backreef area, a reef belt area and a subtidal off-reef area. These facies areas were distributed mainly along a gently dipping carbonate ramp with a land area in the north and an open marine facies area in the south, with only a short period of a rimmed shelf stage in carbonate platform evolution (Hofmann \& Keller, 2006).

\subsubsection{Cabornera Bed}

Facies type 2 (FT2): micritic dark-grey and black limestones

Description: Dark-grey to black wackestones and lime-mudstones, irregularly thin bedded, ranging between 1-10 cm (Fig. 11C, D). The limestone is very poor in fossils. In the lighter parts a few crinoid ossicles were found. In both sections a brachiopod coquina bed of FT3 is intercalated within the upper part of the facies succession.

Interpretation: The dark-grey and locally black colour of the sediments and the paucity of benthic organisms suggest local low-oxygen bottom-water conditions (Lüning et al., 2004). The moderate production of organic carbon was insufficient for black shale formation. The upward change from grey limestones with some macrobiota to dark-grey, barren micritic limestones in the basal part of the Cabornera Bed reflects the transition from slightly oxygen-depleted dysaerobic conditions to highly oxygen-depleted anaerobic depositional conditions (Tyson \& Pearson, 1991) in which nutrient-rich mud settled down. In this facies type there are no sedimentological indications for traction currents, based on which it is assumed that the carbonates 

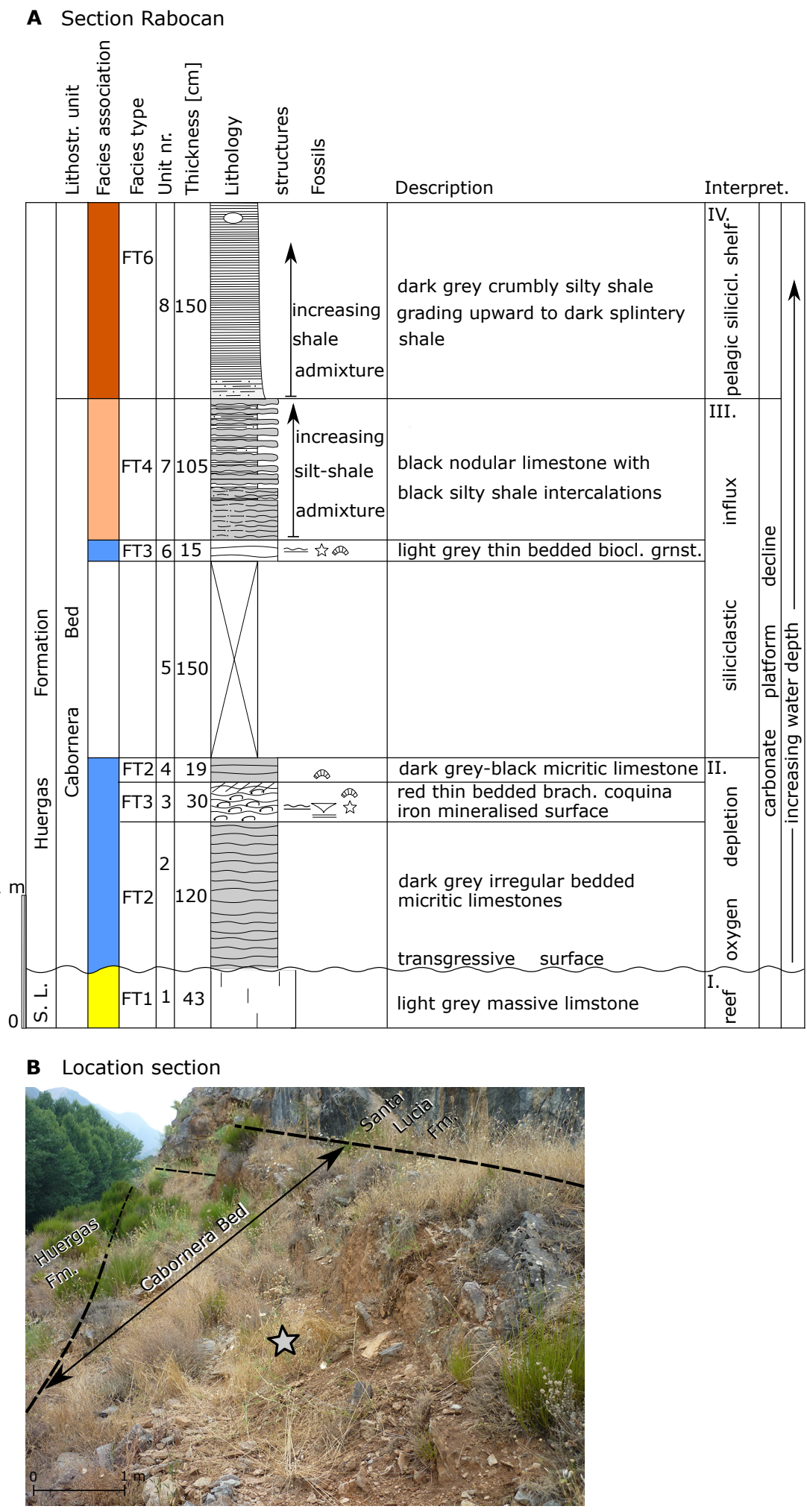

Fig. 10. A - Stratigraphy and interpretation of the Rabocan section; B - Location of the section. For legend see Fig. 9.

formed in the quiet parts of the outer shelf below storm wave base.

Facies type 3 (FT3): light grey and red brachiopodal limestones
Description: This facies type consists of light-grey and red bioclastic limestones with thin light-grey to yellow silty laminae between the beds. The limestones are nodular, thin bedded, with beds ranging 
between 1 and $5 \mathrm{~cm}$ in thickness (Fig. 11B). They are classified as bioclastic packstones and grainstones, and are often ripple laminated. This facies is very rich in fossils. At some levels almost the entire limestone is made up of brachiopods, based on which these beds are classified as brachiopod coquinas, although overall bryozoans and crinoids also occur in large numbers. Iron mineralisation surfaces with iron concretions occur in the upper part of the coquina beds. This facies type occurs at two stratigraphical levels. The lower level (Figs 9, 10: unit 3 in sections) is intercalated within the dark limestones (FT2), and contains coquinas and a mineralisation surface; the upper level is less well developed and occurs immediately above the unexposed part of the Rabocan section. Fernández Martínez et al. (2003) described a heterocoral fauna from what appears to be approximately the same stratigraphical level. The coral fauna occurs in irregularly bedded grainstones with clayey intercalations and iron mineralisations, formed mainly by bryozoan and crinoidal debris, in a section near the study area $(5 \mathrm{~km}$ west of Cabornera).

Interpretation: The ripple lamination and light-grey colour of the sediment indicate deposition under well-aerated, high-energy conditions. The brachiopod-rich beds may have resulted from multiple reworking and amalgamation events in a storm-dominated environment (Einsele, 1992). The coquinas are intercalated within the low-energy, oxygen-depleted environment of facies type FT2. The relation of the beds to these dark limestones indicates that the tempestites were deposited below, but near storm wave base. The tempestites may represent organisms washed in from shallower environments (as indicated by reworking). Alternatively, as the deposits coincide with a relative sea-level fall, major storms may have temporarily created a well-aerated environment in which the organisms grew up and were subsequently reworked, as described by Molina et al. (1997) for Jurassic calcareous tempestites in a pelagic facies in the Betic Cordillera. The upper surface of the tempestite bed of unit 3 is locally mineralised with iron. The key physical factor for the genesis of a ferruginous coating is a sediment-starved, well-oxygenated marine environment (Burkhalter, 1995); thus, the ferruginous horizon indicates a period of sediment starvation after short-lived, turbulent tempestite conditions.

Facies type 4 (FT4): micritic, dark-grey to black limestones and silty shales

Description: This facies type consists of dark-grey to black lime-mudstones with dark-grey silt and shale intercalations. The limestones are thin, irregularly bedded (Fig. 11C, D). Locally, the silt and shale are homogeneously admixed with the limestone, resulting in a crumbly bed form (Fig. 9: unit 8 of the Buiza section). This facies type is very poor in fossils.

Interpretation: The black colour of the sediment and the paucity of benthic organisms suggest local low-oxygen conditions (Arthur et al., 1990). The dark shale intercalations were deposited out of suspension below storm wave base further down slope, where carbonate deposits interfinger with outer shelf mud.

Facies type 5 (FT5): dark-grey shales

Description: This facies type consists of dark-grey, crumbly silty shale. No fossils were found in the shales. The shales rest with a gradational contact on the silty micritic limestones of FT4.

Interpretation: This facies documents clay deposition out of suspension below storm wave base. A few brief intervals occur in which silt was introduced. The absence of macrobiota could be due to stressed, oxygen-depleted bottom conditions, and/or the absence of a stable substrate. The dark-grey colour of the barren sediment indicates oxygen-depleted and nutrient-enriched sea water conditions (Rimmer, 2004); a depositional setting very similar to that of the Huergas shales.

\section{Huergas Formation}

Facies type 6 (FT6): fissile dark shale

Description: The lower part of the Huergas Formation consists of dark-grey, crumbly silty shale and fissile pure shales with graded sandy silt laminations (Fig. 11A). The silt intercalations are a few centimetres thick, with a cross-laminated basal part and a fining-upward upper part. These silt beds can be traced over large distances. The facies is very poor in fossils. Silt nodules with a diameter of several centimetres and a ferruginous crust occur in the fissile shale.

Interpretation: This facies was deposited entirely out of suspension beyond the carbonate-producing area, below storm wave base. During brief intervals storm-enhanced currents delivered silt to a depth below storm wave base, where mud accumulated during fair-weather conditions (Nichols, 2009; fig. 14.1). The silt intervals indicate a distal pelagic environment outside the coastal ranges. The darkgrey colour, the concretions and the paucity of fossils indicate slow accumulation of sediment in an oxygen-depleted, euxinic and nutrient-enriched environment. Similar deposits were described by Lüning et al. (2004) for the lowermost Frasnian of the Algerian Ahnet Basin in northwest Africa with deposition of dark, hemipelagic bituminous muds and thin sand layers resulting from intermittent storm activity. 


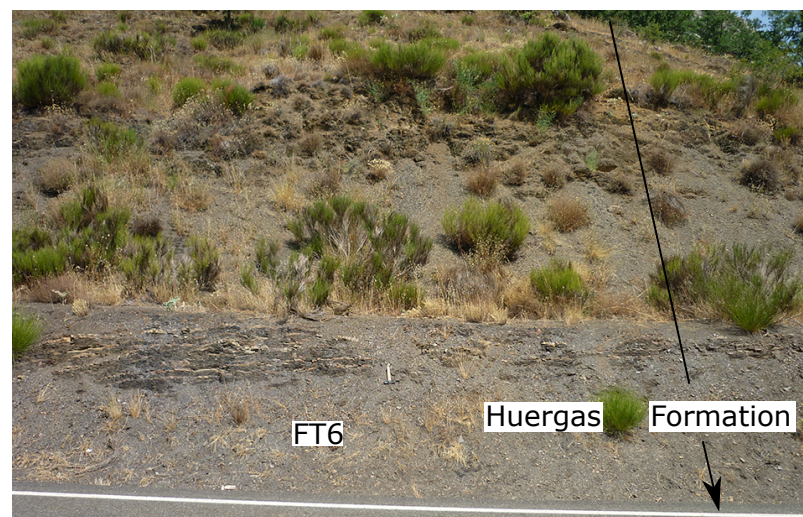

(A)

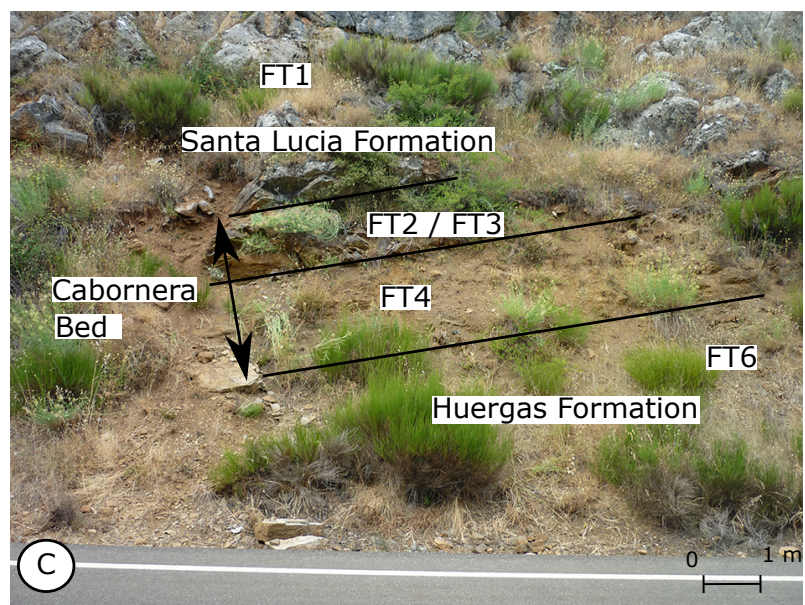

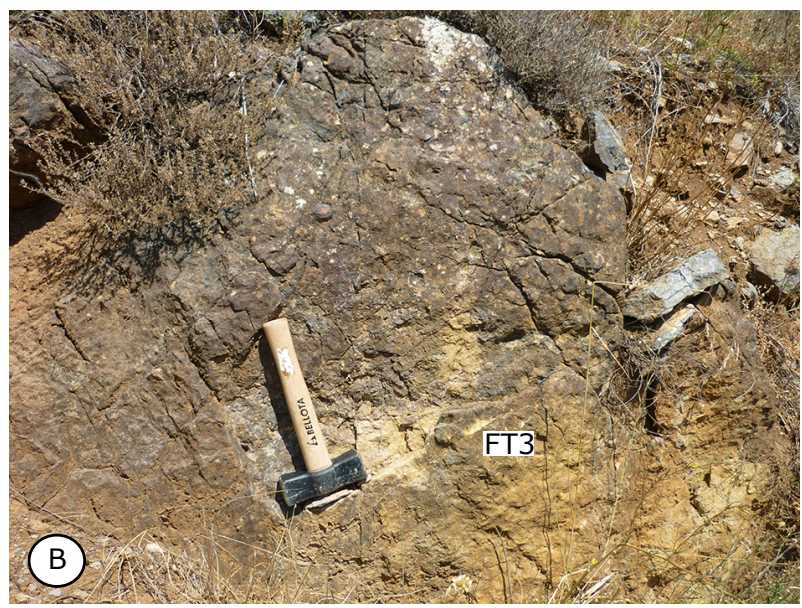

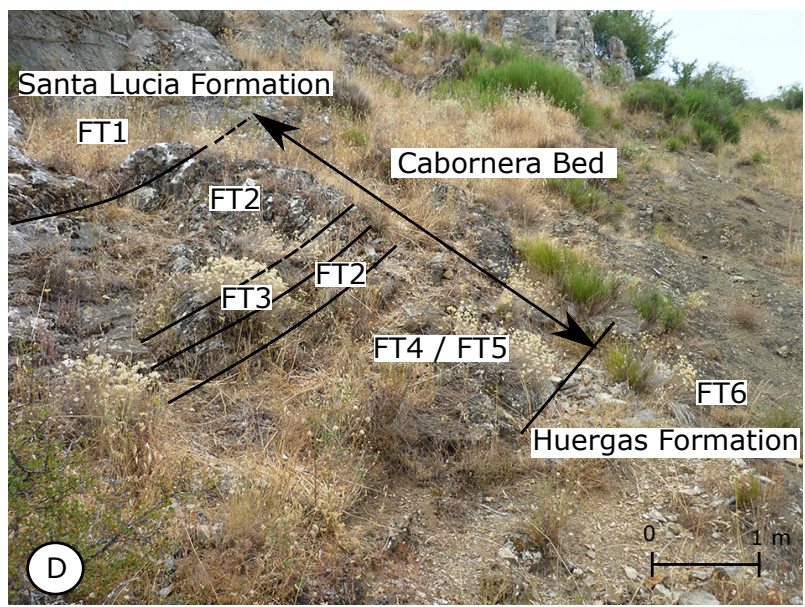

Fig. 11. A - Huergas Formation: splintery shales with few siltstone beds; $250 \mathrm{~m}$ west of Buiza section, north of the road to Cabornera; B - Brachiopod coquina (FT3); Rabocan section; C - Cabornera Bed with micritic limestones (FT2) and brachiopod coquina (FT3) at the base, overlain by silty limestones (FT4) grading upwards into calcareous shales; 200 m west of Rabocan section; D - Cabornera bed with micritic limestone (FT2) and brachiopod coquina (FT3) overlain by silty limestones (FT4) and shales (FT5); Buiza section.

\section{Facies stackings}

A brief description of the facies succession and the main lithological characteristics of the two measured sections are given, including the uppermost part of the Santa Lucía Formation, the Cabornera Bed and the lowermost part of the overlying Huergas Formation.

\section{Buiza section}

This section is located $500 \mathrm{~m}$ north of Beberino at the road junction to Buiza on the eastern side of the road (Figs. 2C, 9, 11D). A 3.72-m-thick succession of Cabornera Beds rests with a sharp contact on the underlying light-grey fossiliferous limestone of the Santa Lucía Formation. The base of the succession consists of light-grey, thin-bedded micritic limestone (FT2) with a few crinoid ossicles, grading upwards into dark-grey, barren limestone. In the upper part of the FT2 succession, $1.2 \mathrm{~m}$ above the base, a 0.2-m-thick unit of light-grey and red brachiopod coquina (FT3) is intercalated, capped by 0.2 $\mathrm{m}$ of black limestone with a bryozoan fauna (FT2). Above it a 2.12-m-succession of dark-grey nodular silty micrite and shale occurs (FT4, FT5), organised in two fining-upward cycles, followed by dark-grey silty shale of the Huergas Formation (FT6).

\section{Rabocan section}

This section is located 100 m west of the Rabocan campsite and restaurant, north of the road to Cabornera (Figs. 2C, 10). The contact of the 4.39-m-thick Cabornera succession with the light-grey Santa Lucía limestones (FT1) is a sharp bedding plane. Above it a 1.2-m-thick unit of dark-grey micritic limestone (FT2) is overlain by $0.3 \mathrm{~m}$ of red-coloured, ferruginous brachiopod coquina (FT3; Fig. 11B). The coquina is capped by $0.19 \mathrm{~m}$ of dark-grey micritic 


\section{Huergas Formation}

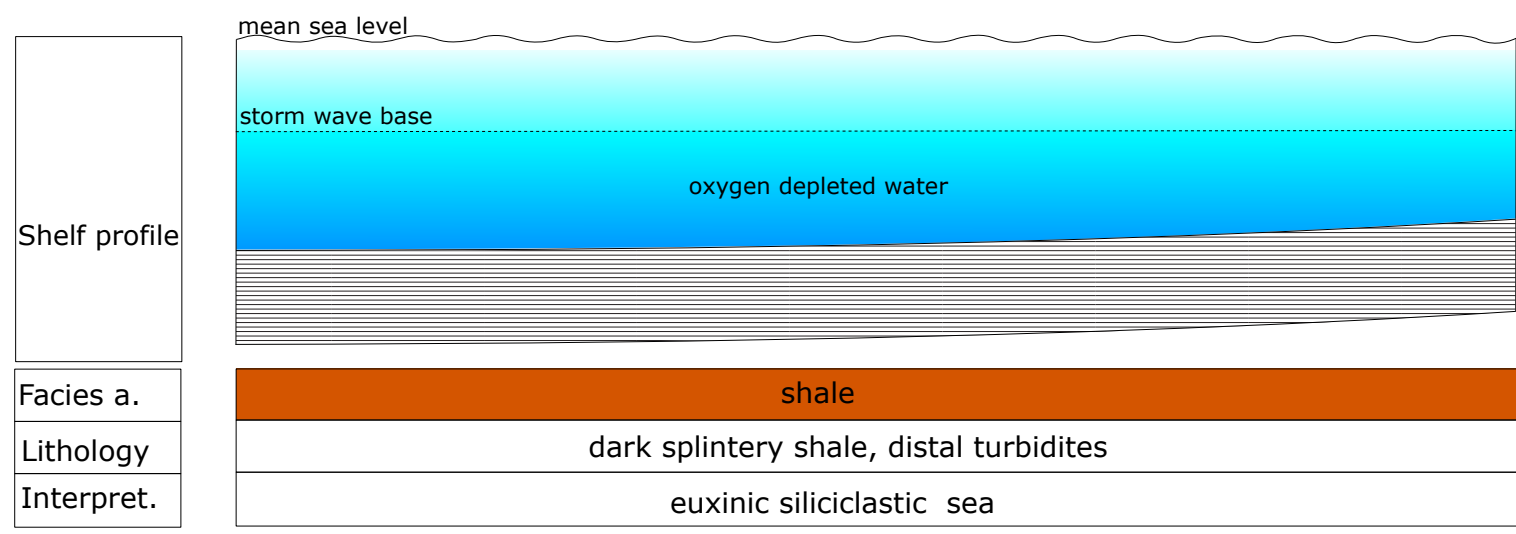

\section{B Cabornera Bed}

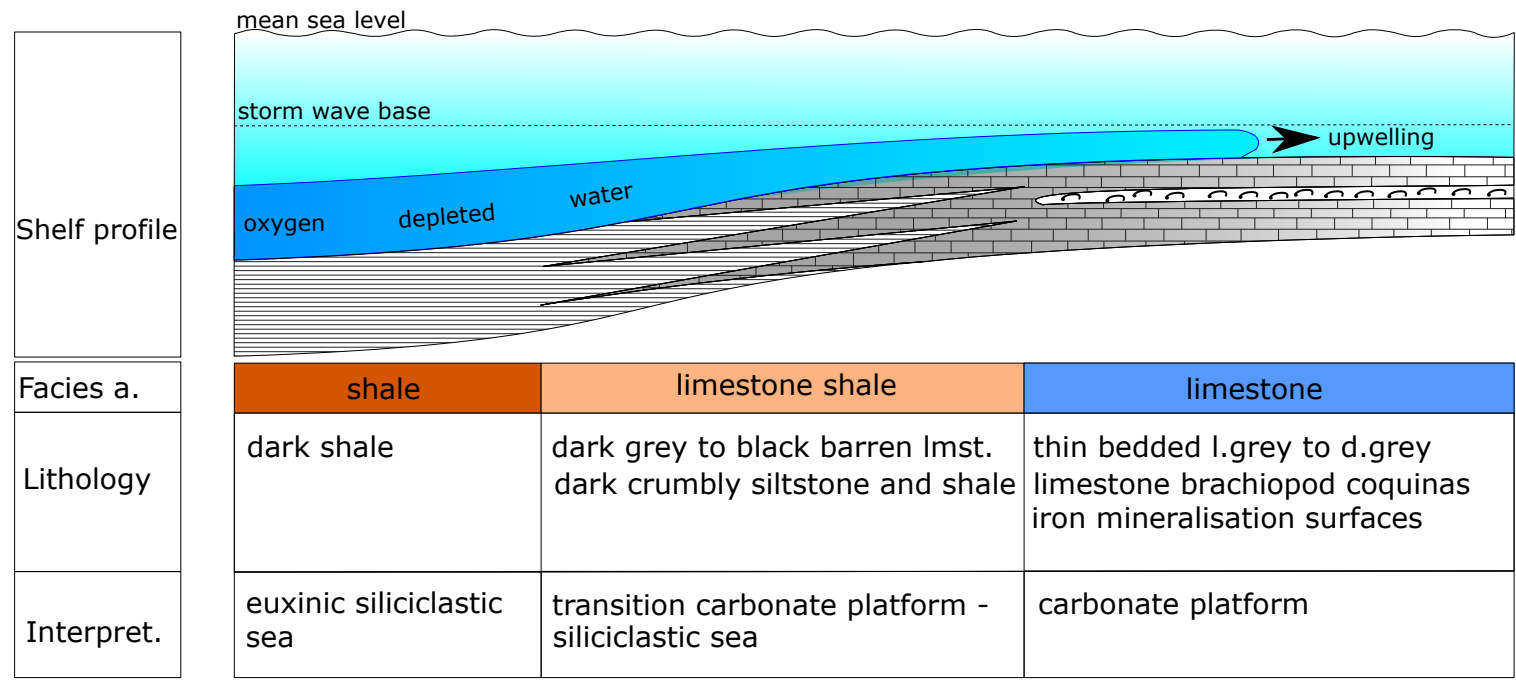

\section{A Santa Lucia Formation}

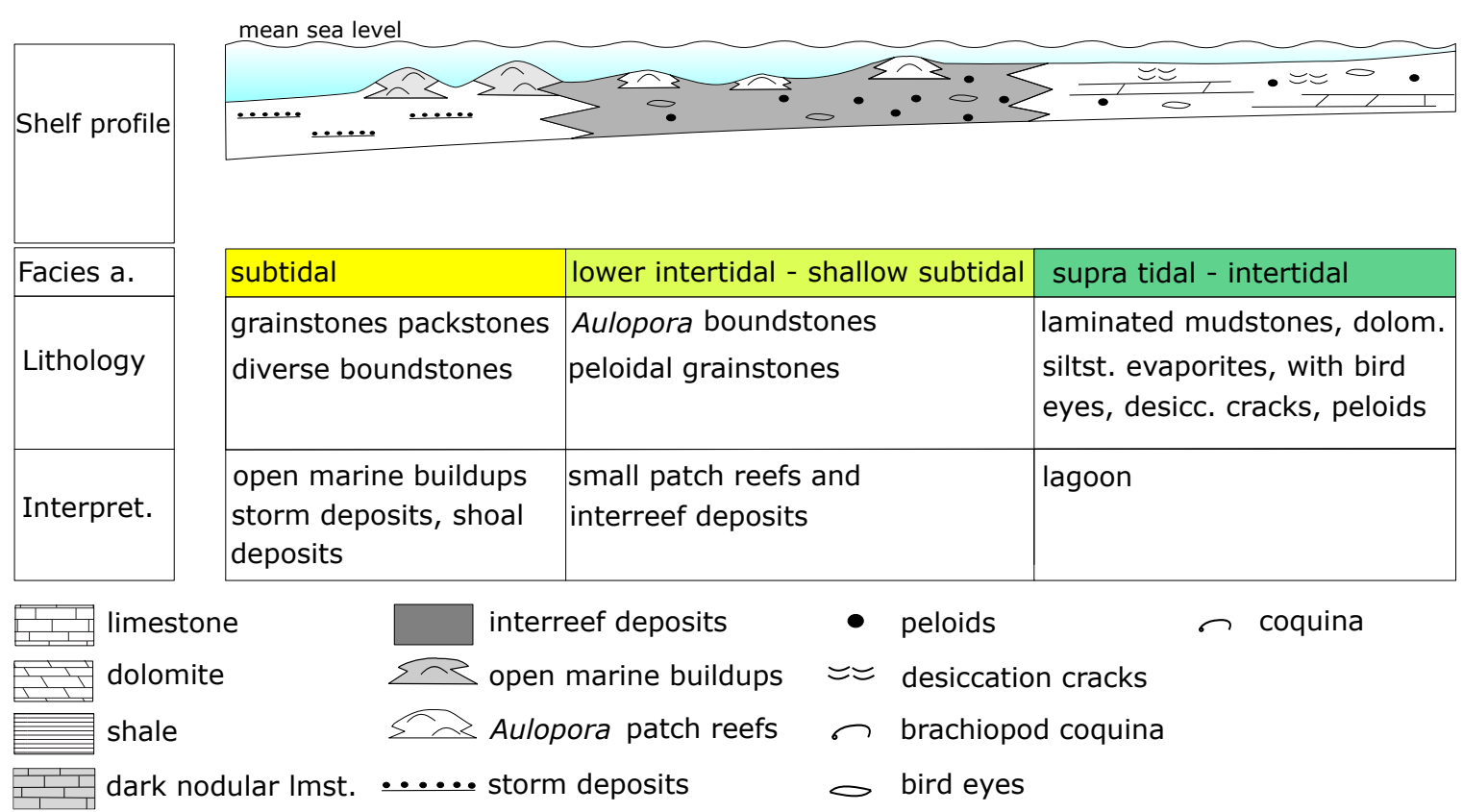


Fig. 12. A - Sedimentation model of the Santa Lucía Formation (interpretation using data supplied by De Coo (1974), Méndez Bedia (1976), Buggisch et al. (1982), Hofmann \& Keller (2006) and our own data; B - Sedimentation model of the Cabornera Bed; C - Sedimentation model of the Huergas Formation. Facies a. = Facies association.

limestone with a bryozoan fauna (FT2). The next 1.5 $\mathrm{m}$ is not exposed, but laterally of the section dark shaly silt with limestone intercalations occurs at this stratigraphical level. Above it a $0.15-\mathrm{m}$-unit of lightgrey, ripple-laminated bioclastic limestone (FT3) occurs. The uppermost part of the Cabornera Bed consists of $1.05 \mathrm{~m}$ of black nodular limestone and silty shale in a fining-upward succession (FT4). The lowermost part of the overlying Huergas Formation consists of $0.40 \mathrm{~m}$ of dark-grey, crumbly silty shale which grades upwards into pure fissile shale with silt nodules and graded silt laminae (FT6).

\section{Depositional models}

\section{Santa Lucía Formation}

Only the uppermost metres of the Santa Lucía Formation below the boundary surface with the overlying Cabornera Bed were studied (Figs. 9, 10). In order to reconstruct the depositional model of the complete Santa Lucía Formation, also data supplied by De Coo (1974), Méndez Bedia (1976), Buggisch et al. (1982) and Hofmann \& Keller (2006) were used. In the present study the proposed subdivision of Hofmann \& Keller (2006) will be followed, with three facies associations (Fig. 12A):

- Supratidal to intertidal facies association:

This association is characterised by laminated mudstones, dolomites, marlstones, siltstones and gypsum, with birdseyes, desiccation cracks, laminoid-fenestral fabrics and peloids. The rocks formed in a lagoonal setting, bounded to the north by the Asturian Geanticline and by a reef belt towards the south.

- Lower intertidal - shallow, subtidal facies association:

This facies association is characterised by $\mathrm{Au}$ lopora boundstones and peloidal grainstones. These rocks represent small patch reefs, biostromes and inter-reef sediments, deposited landward of the main reef complex.

- Subtidal facies association:

This facies association consists of grainstones, packstones and highly diverse boundstones; bafflestones with rugose corals, Thamnopora and dendroid bryozoans; framestones with colonial rugose corals and massive tabulate corals and bindstones with stromatoporoid buildups. The boundstones represent open-marine reef build-ups, typical of the seaward, high-energy margin of the reef; the grainstones and packstones represent storm and shoal deposits.

Close to the Asturian Geanticline, in the inner part of the Asturo-Leonese shelf area, the backreef/peritidal environment dominated with locally high terrigenous siliciclastic input. In the outer part of this shelf a subtidal open-marine environment dominated. The basic shelf morphological picture is that of a carbonate ramp with a gentle-dipping slope from the Asturian Geanticline and the inner part of the shelf towards the outer part of the shelf (De Coo, 1974; Méndez Bedía, 1976; Buggisch et al., 1982; Hofmann \& Keller, 2006).

\section{Cabornera Bed}

During deposition of the Cabornera Bed the basic shelf morphology remained intact: a gently dipping shelf from the Asturian Geanticline towards the south without any significant rim structures, and a gradual transition between the different depositional areas (Fig. 12B); a limestone facies zone of facies types FT2 and FT3; a limestone-shale facies zone of facies type FT4 and a shale facies zone of facies type FT5.

\section{Limestone facies zone (FT2, FT3)}

These lithologies occur in the basal part of both sections, where they rest, with a sharp contact, on massive light-grey limestones. Below the boundary light-grey reef and reef-related limestones occur; above it the succession includes shales and dark limestones. Although the deepening started during deposition of the light-grey limestones of the Santa Lucía Formation with the rapid deposition of crinoidal limestones (Hofmann \& Keller, 2006), the boundary surface represents the onset of an accelerated deepening. In the Buiza section the rocks of the Cabornera Bed gradually change upwards from light-grey coloured limestones in the basal part with a few fossil imprints, towards dark-grey coloured barren limestones in the upper part, representing the transformation from dysaerobic conditions towards oxygen-depleted anaerobic conditions just below storm wave base. Because of slight depth fluctuations, the storm wave base temporarily reached the bottom and changed the environment into a turbulent zone where storm-enhanced coquinas formed. 


\section{Limestone-shale facies zone (FT4)}

This facies zone is characterised by dark-grey and black limestones and silty shales. In the sections there is an upward increase of shale content which occurs as separate bed intercalations but also admixed with limestone, grading from silty limestone to shaly siltstone. These sediments are exclusively dark-grey to black in colour. The deposits represent a deeper environment, located seawards from the depositional zone of the dark limestones. They formed in an anaerobic setting, in which carbonate sedimentation was gradually replaced by sedimentation of suspended siliciclastic mud.

\section{Shale facies zone (FT5)}

This facies zone is characterised by crumbly silty shale deposits of FT5 type. Shale successions occur in the upper part of the Cabornera Bed and are very similar to the silty shales of the lowermost part of the overlying Huergas Formation. The dark-grey barren strata were deposited away from the coast in an oxygen-depleted euxinic environment, in which only the finest sediments settled down from suspension.

\section{Huergas Formation}

The basal 50 metres of the Huergas Formation start with crumbly shales grading upwards into dark fissile shales (FT6), deposited in a deep and low-energy environment well away from the coastal area, with oxygen-depleted bottom conditions, unfavourable for benthic fauna (Fig. 12C). Thin silt layers were deposited from distal turbidity currents. Silt laminae can be traced over large distances indicating an undisturbed environment.

\section{Carbon isotope stratigraphy}

Carbon isotope analysis was performed on Lower to Middle Devonian carbonates of central and southern Europe by Buggisch \& Mann (2004), and for the Prague Basin by Vodrážková et al. (2013). The following interpretation is based on these papers. The $\delta^{13} \mathrm{C}$ trends at the Škrábku quarry section in the Prague Basin and at the Puerto Creek section in Cantabria (the latter located $6 \mathrm{~km}$ east of the study area) exhibit only minor fluctuations. In order to compare the $\delta^{13} \mathrm{C}$ curves, biostratigraphical conodont data from the literature were used to constrain their ages (García López \& Sanz-López, 2002; Berkyová, 2009). Vodrážková et al. (2013) correlated a small negative excursion close to the partitus Zone in the proximi- ty of the Lower-Middle Devonian boundary in the Prague Basin sections. This geochemical signal (i.e., slight negative peak of $\delta^{13} \mathrm{C}$ ) can be correlated with the geochemical $\delta^{13} \mathrm{C}$ signal of the Puerto Creek section (Fig. 13). However, in the Cantabrian section the negative peak corresponds with the patulus Zone. As, obviously, the validity of the correlation depends on the precision of biostratigraphical data, the lower position of the negative peak could be the result of a paucity of conodonts in the Santa Lucía Formation (García López \& Sanz-López, 2002). It is probable that the first recorded occurrence of the index taxon of the partitus Zone in the Santa Lucía Formation does not represent its real first appearance. The Emsian-Eifelian boundary placement in the Puerto Creek section proposed by Ellwood et al. (2006) is based on magnetostratigraphy (polarity data). They situated the boundary $4.5 \mathrm{~m}$ below the proposed Emsian-Givetian boundary surface of García López \& Sanz-López (2002) (i.e., the first recorded occurrence of the conodont Icriodus retrodepressus Bultynck, 1970). Above the small negative peak of $\delta^{13} \mathrm{C}$ values, a gradual shift of $\delta^{13} \mathrm{C}$ values from c. $1 \%$ o in the partitus Zone to c. $2 \%$ o in the costatus Zone occurs. The Škrábku section of the Prague Basin correlates well with the $\delta^{13} \mathrm{C}$ values of the Puerto Creek section of Cantabria. A comparable low-magnitude gradual positive rise of carbon isotope values has also been recorded from coeval strata elsewhere in Europe (Buggisch \& Mann, 2004) and correlates well with the sea level rise of T-R cycle 1c of Johnson et al. (1985). This long-term gradual shift suggests a trend of progressive burial of organic carbon from the partitus Zone onwards.

\section{Stages of reef decline}

Based on the interpretation of the sections studied a sequence of environmental changes can be recognised which represents the subsequent decline phases of the reef environment, illustrated in Figures 9 and 10.

I. Reef stage (Santa Lucía Formation)

The Santa Lucía strata can be divided into seven, 30-40 m thick, medium-scale cycles (Hofmann and Keller, 2006), corresponding to the classic sequences of sequence stratigraphy of Wagoner et al. (1988) with transgressive and highstand systems tracts (TSTs and HSTs). These medium-scale cycles are part of higher-rank, large-scale cycles. Medium-scale cycle 1 is part of a large-scale cycle that originated in the Esla Formation of the underlying La Vid Group. Medium-scale cycles 2 through 6 form one large-scale cycle completely within the 
PRAGUE BASIN

Skrábku quarry

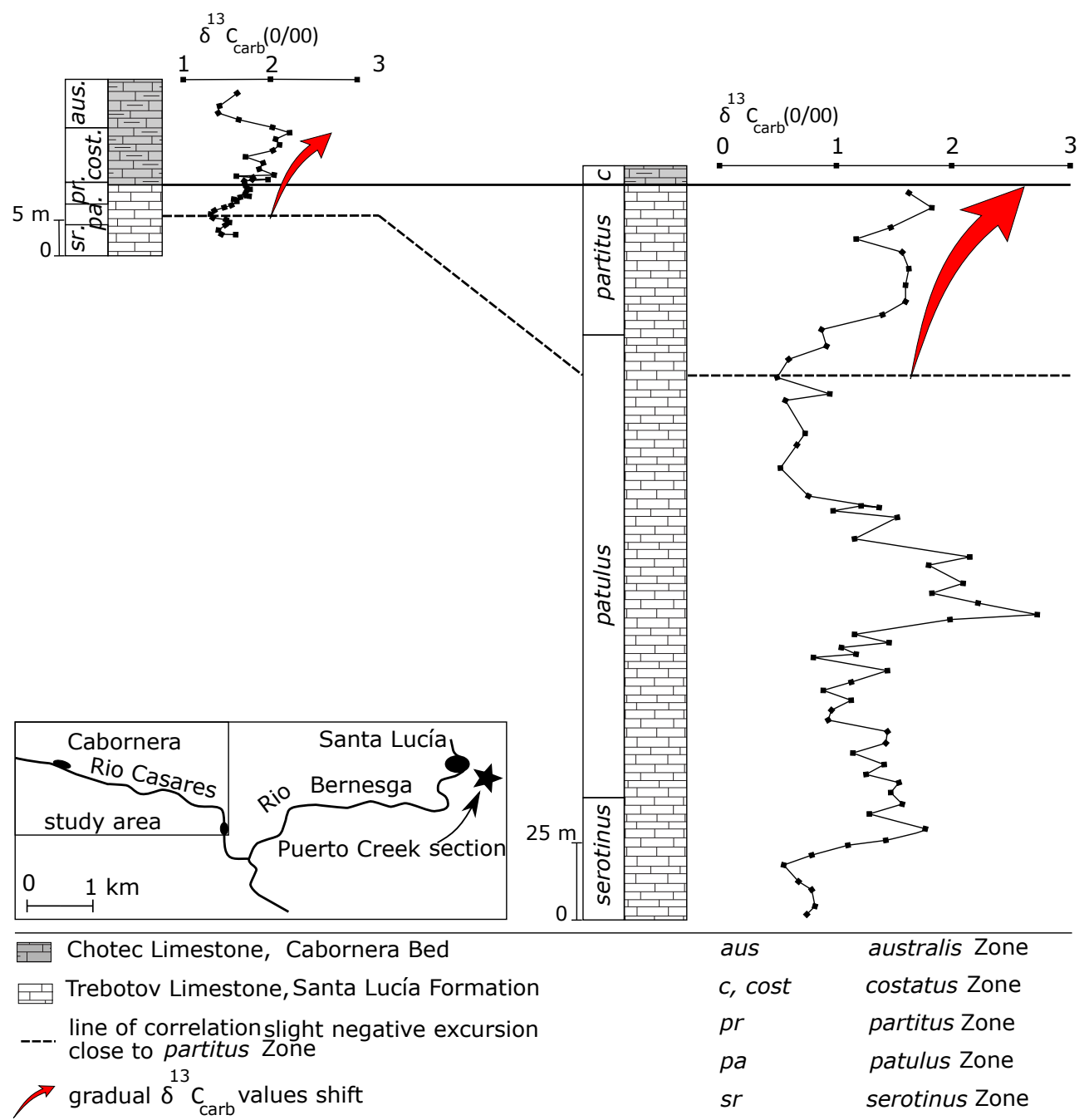

\section{CANTABRIA}

Puerto Creek 
sediment-covered coral surface is killed in less than 24 hours, while nutrient-poor sediments have little effect on reef health. Therefore, it is assumed that nutrient-enriched oxygen-depleted water spread over the carbonate platform, resulting in severe damage to the reef fauna, at least seriously downgrading its growth potential. As the reef lost its capability to compensate for eustatic and tectonic relative sea level changes, the reef drowned and was covered by a condensed sequence of nutrient-rich, dark sediments.

III. Siliciclastic influx stage (Cabornera Bed)

Following the oxygen-depleted stage, an increasing amount of fine siliciclastic sediment was deposited over the former reef area, at the expense of carbonate deposition. Almost all of these fine sediments were deposited out of suspension. The transparency of the water, which determines the depth of the photic zone, crucial for the reef fauna, must have been severely reduced by suspended mud. As strata of stage III are very poor in fossils it is assumed that stage II completed the destruction of the reefs prior to the arrival of the muddy sediments of stage III.

IV.Pelagic siliciclastic shelf stage (Huergas Formation)

As sedimentation slowed down and eustatic sea level rise accelerated, a condensed sequence of siliciclastic muds formed below storm wave base, above the former reefs, far from the coast. No near-coastal sandy deposits are known from stage IV.

\section{Discussion}

The Santa Lucía reefs were constantly exposed to eustatic and tectonically controlled sea level fluctuations (Hofmann \& Keller, 2006). The growth capacity of the reef biota was sufficient to compensate the sea level changes. The light-grey crinoidal limestone succession in the top of the formation marks the onset of another relative sea level rise. On top of these limestone deposits the Cabornera Bed forms a condensed sequence of dark-grey and black micritic limestones and shales, with iron mineralisation surfaces and a few storm-generated brachiopod coquina intercalations.

The lower boundary of the Cabornera Bed is a sharp contact that separates the light-grey reef deposits from the overlying condensed succession. Buggisch et al. (1982) described a thin, condensed dark shale succession with iron concretions on top of the Santa Lucía limestones in the southernmost part of the Asturo-Leonese facies area, which probably can be correlated with the Cabornera Bed.
Moreover, they assumed a stratigraphical gap that encompassed the uppermost strata of the Santa Lucía Limestone and the lower succession of the Huergas Formation. However, Rodríguez Fernández et al. (1985) demonstrated that the anomalous relationship between the Santa Lucía and Huergas formations in the southernmost sections was not due to intra-Devonian erosion but rather to thrusting. In the Cabornera Bed the shale-content gradually increases upwards and the boundary with the overlying Huergas shales is transitional: the sections studied by them contain a sharp erosional contact that documents a sedimentary gap at the base of the Cabornera Bed. Fernández Martínez et al. (2003) described a horizon of grainstone beds with clayey intercalations and iron mineralisation, $4 \mathrm{~m}$ below the top of the Santa Lucía Formation, south of Geras (5 $\mathrm{km}$ west of Cabornera). This horizon probably belongs to the Cabornera Bed. It is expected that the condensed sequence of the Cabornera Bed has a regional distribution and can be found in large parts of the Asturo-Leonese facies area.

The study of the stratigraphical and sedimentary characteristics of the Cabornera Bed clarifies the environmental evolution of the Early-Middle Devonian shelf area, the order of stages of reef decline and finally the disappearance of the Santa Lucía reefs:

Conodont assemblages from the uppermost part of the Santa Lucía Formation are from the partitus Zone or costatus Zone, and the overlying Cabornera Bed contains an assemblage of the costatus Zone (García López \& Sanz-López, 2002). The bounding surface between the reef and the overlying Cabornera Bed is para-conformable, resembling a simple sharp bedding plane. Apparently, there was no sedimentary erosion prior to deposition of the Cabornera Bed.

The basal dark-grey and black nodular limestones and the impoverished benthic fauna indicate an oxygen-depleted environment caused by nutrient-enriched water. As the water spread over the carbonate platform it severely damaged the reef fauna. The high rate of organic matter and subsequent degradation caused oxygen deficiency (Rimmer, 2004). Reworked bioclastic material and calciturbidites that originated from shallow water, as described from the Choteč Limestone of the Škrábku section, are absent. No reef elements occur above the lower boundary of the Cabornera Bed, indicating that these nutrient-enriched waters terminated reef formation.

In the upper half of the Cabornera Bed the dark barren limestone deposits are gradually replaced by dark shales. Therefore, it is concluded that the 


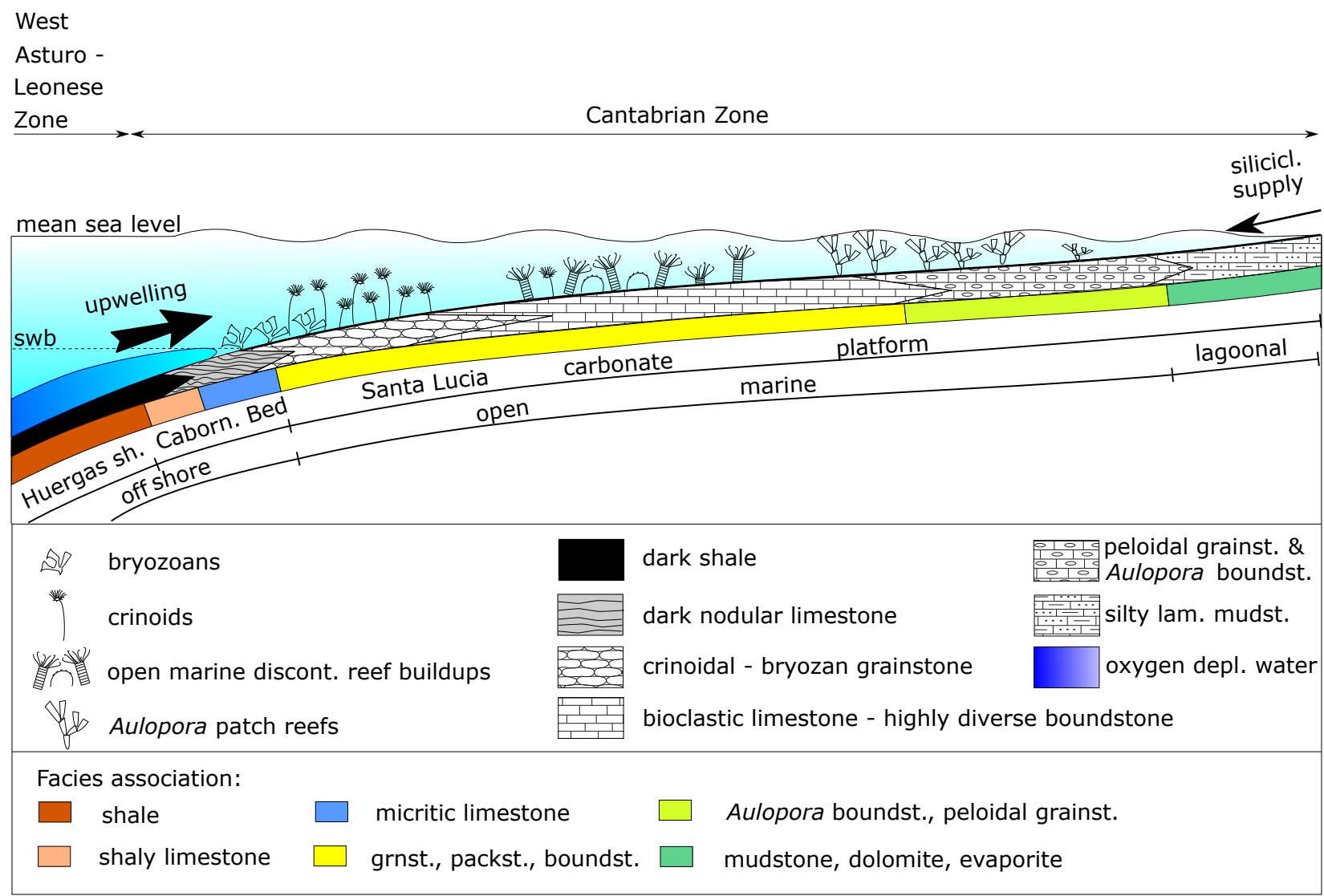

Fig. 14. Upwelling and flooding of cold, oxygen-depleted and nutrient-enriched water from the deeper pelagic areas of the surrounding West Asturo-Leonese Zone onto the shallow-marine shelf areas of the Cantabrian Zone, related to a transgressive period that introduced an organic-rich mud environment within the carbonate shelf sea.

reefs gave way to deposition of siliciclastic mud from suspension, shallowing the photic zone.

As the reef starved there no longer was a carbonate production mechanism to compensate sea level rise, and at an increasingly higher rate the depositional environment changed towards one with pelagic mud.

The main trigger for the disappearance of the Early/Middle Devonian carbonate platform is the introduction of oxygen-depleted and nutrient-enriched waters onto the carbonate shelf, reducing the growth potential of the reef fauna. Therefore, reef growth could no longer compensate the relative sea level rise, which already started during formation of the last reef deposits of the Santa Lucía Formation. The increase in water depth was a result of the disappearance of the reef platform, rather than its cause.

There was a gradual change from the Silurian-Early Devonian continental passive margin setting with extensive shallow-marine platforms on which sedimentation was mainly controlled by eustatic processes towards Late Devonian tectonically controlled active margin type settings with platforms at the edge of an extended and uplifted hinterland (Van Loevezijn, 1989; Keller et al., 2008). Deposition of the Santa Lucía succession was controlled mainly by eustatic sea-level changes, but with a distinct tectonic component (Fig. 3), resulting in the well-stratified, persistently bedded appearance of the formation (Fig. 4). This differs from the younger Devonian reef units: the Givetian Portilla reef deposits were tectonically controlled and therefore over short distances vary significantly in thickness and facies (Reijers, 1972; Raven, 1983). Locally, the boundary between the Givetian reefs of the Portilla Formation and the overlying Frasnian siliciclastic shelf deposits of the Nocedo Formation is clearly erosive, as demonstrated in facies correlation transects by Reijers (1974) and Raven (1983). A spectacular undulating erosional contact between the Givetian reef deposits and the overlying Frasnian siliciclastics can be observed at the road section near Beberino, close to the study area. Van Loevezijn (1989) demonstrated that also the last Frasnian reef (the Crémenes Limestone) was controlled by tectonically induced sedimentary processes. Thus, Early/Middle Devonian reef 
platforms disappeared due to an environmental change, caused by a high nutrient supply and oxygen depletion as a result of degradation of organic matter (Fig. 14). The Late Devonian reef platforms, however, were replaced by siliciclastic shelf deposits linked to erosion and siliciclastic input, caused by tectonically controlled accommodation space and erosion (Van Loevezijn, 1989).

\section{Conclusions}

The evolution of the carbonate depositional system in the Asturo-Leonese facies during costatus Zone time is described on the basis of facies analysis of the boundary interval between the fossiliferous Santa Lucía limestone and the Huergas shales. The transition from light-grey fossiliferous limestones of the Santa Lucía Formation to the darker-coloured and more thinly bedded Cabornera Bed marks the onset of the environmental change linked to the Basal Choteč Event.

The absence of macrofauna in the dark mudstone beds of the Cabornera Bed could be indicative of unfavourable, quasi-anaerobic, stressed bottom conditions (Tyson \& Pearson, 1991). The dark-grey and black bituminous nature of these deposits could be an indication of oxygen depletion (Arthur \& Sageman, 2004). Upwelling from the outer deeper sea of oxygen-depleted, nutrient-enriched water during sea level rise is here proposed as a plausible nutrient source.

The recorded depositional deepening, as demonstrated in the Cabornera Bed, is regarded as the result, and not the primary cause, of the disappearance of the main Devonian carbonate platform in the Cantabrian Mountains.

Evolution of Lower-Middle Devonian sedimentary environments in the study area is based mainly on sedimentological and palaeontological studies; these have to be verified by future geochemical and geophysical investigations.

\section{Acknowledgements}

We gratefully acknowledge thoughtful comments made by A. van Loevezijn-Peña and M. Schluter (Nederlandse Aardolie Maatschappij) on an early version of the manuscript. Constructive reviews by Thomas Suttner (Austrian Academy of Sciences) and an anonymous reviewer considerably improved the paper.

\section{References}

Aramburu, C., Méndez-Bedia, I., Arbizu, M. \& García López, S., 2004. La sequencia preorogénica. [In:] Vera, J. A. (Ed.): Geología de España, Sociedad Geológica de España, Instituto Geológico y Minero, Madrid, 27-34.

Arthur, M.A., Brumsack, H.J., Jenkyns, H.C. \& Schlanger, S.O., 1990. Stratigraphy, geochemistry, and paleoceanography of organic carbon-rich Cretaceous sequences. [In:] Ginsburg, R.N. \& Beaudoin B. (Eds): Cretaceous Resources, Events and Rhythms. Kluwer Academic Publishers, Dordrecht, 75-119.

Arthur, M.A., \& Sageman, B.B., 2004. Sea level control on source rock development: perspectives from the Holocene Black Sea, the Mid Cretaceous Western Interior Basin of North America, and the Late Devonian Appalachian Basin. [In:] Harris, N.B. (Ed.): The Deposition of Organic-Carbon-Rich Sediments: Models, Mechanisms and Consequences. Society for Sedimentary Geology Special Publication 82, 35-59.

Berkyová, S., 2009. Lower-Middle Devonian (Upper Emsian-Eifelian, serotinus-kockelianus zones) conodont faunas from the Prague Basin, the Chech Republic. Bulletin of Geosciences 84, 667-686.

Brouwer, A., 1964. Deux facies dans le Dévonien des Montagnes Cantabriques Meridionales. Brevoria Geológico Asturica 4, 3-10.

Buggisch, W. \& Mann, U., (2004). Carbon isotope stratigraphy of Lochkovian to Eifelian limestones from the Devonian of central and southern Europe. International Journal of Earth Science 93 (4), 521-541.

Buggisch, W., Meiburg, P. \& Schumann, D., 1982. Facies, Palaeogeography and Intra-Devonian stratigraphic gaps of the Asturo-Leonese Basin (Cantabrian Mts / Spain). Neues Jahrbuch für Geologie und Paläontologie Abhandlungen 163, 212-230.

Burkhalter, R.M., 1995. Ooidal ironstones and ferruginous microbiolites: origin and relation to sequence stratigraphy (Aalenian and Bajocian, Swiss Jura mountains). Sedimentology 42, 57-74.

Comte, P., 1959. Recherches sur les terrains anciens de la cordillère Cantabrique. Memorias del Instituto Geológico y Minero 60, 440 pp.

Coo, J.C.M. de, 1974. Lithostratigraphy of the Devonian Santa Lucía Limestones in Leon, Spain. Thesis, University of Leiden, $87 \mathrm{pp}$.

Copper, P. \& Scotese, C.R. 2003. Megareefs in Middle Devonian supergreenhouse climates. [In:] Chan, M.A. \& Archer, A.W. (Eds): Extreme depositional environments: Mega end members in geologic time : Boulder, Colorado. Geological Society of America Special Paper 370, 209-230.

Einsele, G., 1992. Sedimentary Basins, Evolution, Facies and Sediment Budget. Springer, Berlin Heidelberg, 792 pp.

Ellwood, B.B., García-Alcalde J.L., Ahmed El Hassani, A.E., Hladil, J., Soto, F.M., Truyóls-Massoni, M., Weddige, K. \& Koptikova, L., 2006. Stratigraphy of the Middle Devonian boundary: Formal definition of the susceptibility magnetostratotype in Germany with comparisons to sections in the Czech Republic, Morocco and Spain. Tectonophysics 418, 31-49. 
Elrick, M., Berkyová, S., Klapper, G., Sharp, Z., Joachimsky, M. \& Frýda, J., 2009. Stratigraphic and oxygen isotope evidence for My-scale glaciation driving eustasy in the Early-Middle Devonian greenhouseworld. Palaeogeography, Palaeoclimatology, Palaeoecology 276, 170-181.

Fernández Martínez, E., Tourneur, F. \& López-Alcantara, A., 2003. A new Middle Devonian heterocoral from Spain. Acta Palaeontologica Polonica 48, 531-546.

Frankenfeld, H., 1984. Deckenbewegungen im Namur des ostliches Kantabrischen Gebirge und die damit verbundenen Vorstellungen uber die Palaeogeographie der Namur- und pre-Namur-Schichten. Zeitung der Deutschen Gesellschaft für Geowissenschaften 135, 223-241.

García Alcalde, J.L., 1998. Devonian events in northern Spain. Newsletter on Stratigraphy 36, 157-175.

García López, S. 1987. Los conodontos y su applicación al estudio de las divisiones cronostratigráficas mayores del Devónico Asturleonés (España). Publicaciones especiales del Boletín Geológico y Minero de España, 1-112.

García López, S. \& Sanz-López J., 2002. Devonian to Lower Carboniferous conodont biostratigraphy of the Bernesga Valley section (Cantabrian Zone, NW Spain). [In:] García López, S. \& Bastida, F. (Eds): Palaeozoic conodonts from Northern Spain. Instituto Geológico y Minero Cuadernos del Museo Geominero 1, 163-205.

García Ramos, J.C., 1978. Estudio e interpretación de las principales facies sedimentarias comprendidas en las formaciones Naranco y Huergas (Devónico medio) en la Cordillera Cantábrica. Trabajos de Geología 10, 195-247.

Hofmann, M.H. \& Keller, M., 2006. Sequence stratigraphy and carbonate platform organization of the Devonian Santa Lucía Formation, Cantabrian Mountains, NW Spain. Facies 52, 149-167.

House, M.R., 1996. The Middle Devonian Kačak Event. Proceedings of the Ussher Society 9, 79-84.

Johnson, J.G., Klapper, G. \& Sandberg, C.A., 1985. Devonian eustatic fluctuations in Euramerica. Geological Society of America Bulletin 96: 567-587.

Keller, M., Bahlburg, H. \& Reuther, C.D., 2008. The transition from passive to active margin sedimentation in the Cantabrian Mountains, Northern Spain: Devonian or Carboniferous? Tectonophysics 461, 414-427.

Kiessling, W., Flügel, E. \& Golonka, J., 2003. Patterns of Phanerozoic carbonate platform sedimentation. Lethaia 36, 195-225.

Loevezijn, G.B.S. van, 1988. Upper Devonian to lowermost Carboniferous concretion types and their stratigraphic significance. Trabajos de Geología 17, 57-66.

Loevezijn, G.B.S. van, 1989. Extinction patterns for the Middle-Upper Devonian stromatoporoid coral reefs; a case study from the Cantabrian Mountains. Proceedings Koninklijke Nederlandse Akademie van Wetenschappen B 92, 61-74.

Lotze, F., 1945. Zur Gliederung der Varisziden in der Iberischen Meseta. Geotektonische Forschungen 6, 78-92.

Lüning, S., Wendt, J., Belka, Z. \& Kaufmann, B., 2004. Temporal-spatial reconstruction of the early Frasnian
(Late Devonian) anoxia in NW Africa: new field data from the Ahnet Basin (Algeria). Sedimentary Geology 163, 237-264.

Méndez Bedía, I., 1976. Biofacies y Litofacies de la Formación Moniello-Santa Lucía (Devónico de la Cordillera Cantábrica, NW de España). Trabajos de Geología 9, 1-93.

Méndez Bedía, I., Soto F. \& Fernández-Martínez, E., 1994. Devonian reef types in the Cantabrian Mountains (NW Spain) and their faunal composition. Courier Forschungsinstitut Senckenberg 172: 161-183.

Molina, J.M., Ruiz-Ortiz, P.A. \& Vera, J.A., 1997. Calcareous tempestites in pelagic facies (Jurassic, Betic Cordilleras, Southern Spain). Sedimentary Geology 95-109.

Nichols, G., 2009. Sedimentology and Stratigraphy. $2^{\text {nd }}$ edition. John Wiley \& Sons Ltd., Chichester, 419 pp.

Raven, J.G.M., 1983. Conodont biostratigraphy and depositional history of the Middle Devonian to Lower Carboniferous in the Cantabrian Zone. Leidse Geologische Mededelingen 52, 265-339.

Reijers, T.J.A., 1972. Facies and diagenesis of the Devonian Portilla limestone formation between the river Esla and the Embalse de la Luna, Cantabrian Mountains, Spain. Leidse Geologische Mededelingen 47, 163-217.

Reijers, T.J.A.,1974. Hinge movements influencing deposition during the Upper Devonian in the Esla Area of the Cantabrian Mountains, Spain. Geologie en Mijnbouw 53, 13-21.

Rimmer, S.M., 2004. Geochemical paleoredox indicators in Devonian-Mississipian black shales, Central Appalachian Basin (USA). Chemical Geology 206, 373-391.

Rodríguez Fernández, L.R., García Alcalde, J.L. \& Menéndez Álvarez, J.R., 1985. La succession del Devónico Superior y Carbonifero Inferior en el synclinal de Alba (León, N.O. de España). Compte Rendu X Congrès International de Stratigraphie et de Géologie du Carbonifére, Madrid 1983 1, 133-144.

Scotese, C.R., 2014. Atlas of Devonian Paleogeographic Maps, Atlas for Arcois 4, The Late Paleozoic, Maps 65-72, Mollweide Projection, PALEOMAP Project, Evanston, IL.

Staalduinen, C.J. van, 1973. Geology of the area between the Luna and Torío rivers, southern Cantabrian Mountains, NW Spain. Leidse Geologische Mededelingen 49, 167-205.

Struve, W., 1982. The Eifelian within the Devonian frame, history, boundaries, definitions. Courier Forschungsinstitut Senckenberg, 55, 401-432.

Tyson, R. \& Pearson, T.H., 1991. Modern and ancient continental shelf anoxia. Geological Society, London, Special Publications. 58, 1-24.

Veselovsky, Z., Bechstadt, T. \& Zuhlke, R., 2008. Structural, reverse-basin and forward stratigraphic modelling of the southern Cantabrian Basin. [In:] De Boer, P., Postma, K., Van der Zwan, K., Burgess, P. \& Kukla, P. (Eds): Analogue and numerical modelling of sedimentary systems: from understanding to prediction. International Association of Sedimentologists Special Publication 40, 65-97.

Vodrážková, S., Frýda, J., Suttner T.J., Koptíková, L. \& Tonarová, P., 2013. Environmental changes close to 
the Lower-Middle Devonian boundary; the Basal Choteč Event in the Prague Basin (Czech Republic). Facies 59, 425-449.

Vodrážková, S., Klapper, G. \& Murphy, M.A., 2011. Early Middle Devonian conodont faunas (Eifelian, costatus-kockelianus zones) from the Roberts Mountains and adjacent areas in central Nevada. - Bulletin of Geosciences, 86, 737-764.

Wagoner, J. C. van, Posamentier, H. W. Mitchum, R. M., Vail, P. R., Sarg, J. F., Loutis, T. S. \& Hardenbol, J., 1988. An overview of the fundamentals of sequence stratigraphy and key definitions. SEPM Spec. Publ., 42, 39-45.
Walliser, O.H., 1985. Natural boundaries and Commission boundaries in the Devonian. Courier Forschungsinstitut Senckenberg 75, 401-408.

Weber, M., Beer, D., Lott, C., Polerecky, L., Kohls, K., Abed, R.M.M., Ferdelman, T.G. \& Fabricius, K.E., 2012. Mechanisms of damage to corals exposed to sedimentation. Proceedings of the National Academy of Sciences of the United States of America 109 (24), E1558E1567.

Manuscript received: 9 April 2017 Revision accepted: 5 August 2017 